\title{
PRZEBIEG I CHARAKTER ZJAWISK LODOWYCH NA WYBRANYCH ODCINKACH RZEK PRZYMORZA O WYSOKIM STOPNIU ANTROPOPRESJI NA TLE ZMIAN KLIMATYCZNYCH ZACHODZĄCYCH W STREFIE BRZEGOWEJ BAŁTYKU
}

\author{
Jan T. Łukaszewicz ${ }^{\bowtie}$ \\ Wydział Nauk Geograficznych i Geologicznych, Uniwersytet im. Adama Mickiewicza w Poznaniu, Poznań
}

\begin{abstract}
STRESZCZENIE
Artykuł przedstawia charakterystykę częstości występowania oraz przebiegu i zmienności zjawisk lodowych na wybranych odcinkach rzek Przymorza, charakteryzujących się wysokim stopniem antropopresji. W pracy wzięto pod uwagę także zmienność form zjawisk lodowych występujących na rzekach, uwzględniając strukturę i rodzaj lodu, jaki występował w poszczególnych fazach zlodzenia tych rzek. Przy analizie zmienności zjawisk lodowych uwzględniono szereg czynników, m.in. położenie odcinka rzeki, na którym prowadzono obserwacje, przepływ wody w profilu rzecznym, zmienność temperatury wody w okresie zimowym i jej wpływ na liczbę dni ze zjawiskami lodowymi na rzekach oraz zmienność temperatury powietrza w okresie zimowym i chłodnym półroczu roku hydrologicznego, czyli główne czynniki warunkujące powstawanie zjawisk lodowych na rzekach. W pracy uwzględniono także przebieg cyrkulacji atmosferycznej, która warunkuje przebieg temperatury powietrza. Do opisania tych zmian wykorzystano wskaźnik oscylacji północnoatlantyckiej (NAO).
\end{abstract}

Słowa kluczowe: zlodzenie, pokrywa lodowa, temperatura, przepływ, zmiany klimatyczne

\section{WSTĘP}

W zlewisku Morza Bałtyckiego zlodzenie rzek jest zjawiskiem powszechnym w sezonie zimowym, co związane jest w sposób bezpośredni z cechami klimatu umiarkowanego. Zjawiska lodowe, będąc nieodłącznym elementem ustroju rzecznego w Polsce, odgrywają niezwykle istotną rolę, szczególnie na odcinkach rzek poddanych antropopresji. Zakłada się, że ekstremalne zjawiska hydrologiczne, takie jak powodzie i niżówki zimowe na rzekach, są w większości efektem występowania i zaniku zjawisk lodowych (Grześ, 1991). Zatem występowanie takich zjawisk na rzekach może nieść za sobą poważne konsekwencje w postaci powodzi zatorowych, które mogą przynieść zarówno istotne straty finansowe, gospodarcze (Janc i Krukowicz, 1987), jak i wyrządzić szkody pozaekonomiczne (społeczne, moralne itp.) - Kiciński i Ciepielowski (1975). Zjawiska te mogą nie tylko w znacznym stopniu wpływać na zmianę reżimu hydrologicznego rzeki, np. poprzez modyfikację przepływu rzecznego oraz zmianę prędkości płynięcia wód w korycie rzecznym, ale mają także istotny wpływ na funkcjonowanie systemu fluwialnego i ekosystemu wodnego, których przejawem jest m.in. brak przepustowości rzeki, spowodowany wystąpieniem pokrywy lodowej. Ekstremalne warunki zlodzenia na rzekach stanowią element modyfikujący warunki przepływu oraz bytowania w nich różnego rodzaju organizmów, często zaburzając ich cykle życiowe (Allan, 1998).

$凶_{\text {janluk@amu.edu.pl }}$ 
Łukaszewicz, J.T. (2017). Przebieg i charakter zjawisk lodowych na wybranych odcinkach rzek Przymorza o wysokim stopniu antropopresji na tle zmian klimatycznych zachodzących w strefie brzegowej Bałtyku. Acta Sci. Pol. Architectura, 16 (1), $93-113$. doi: 10.22630/ASPA.2017.16.1.09.

Istotny wpływ na przebieg zjawisk lodowych i ich zanik mają czynniki środowiskowe o znaczeniu lokalnym, np. charakter koryta rzecznego (quasi-naturalny, silnie przekształcony bądź sztuczny), spadek rzeki, jej autochtoniczność, allochtoniczność, udział wód podziemnych w zasilaniu rzeki, temperatura wód dopływów czy prędkość płynięcia wody uwarunkowana spadkiem terenu. Elementy te wpływają na tworzenie się zjawisk lodowych, które, jak wcześniej wspomniano, mogą przynosić katastrofalne w skutkach powodzie zatorowe (Majewski, 1985, 1987; Grześ, 1991).

Nasuwa się zatem pytanie, w jaki sposób można ustrzec się przez negatywnymi konsekwencjami, jakie niosą za sobą zjawiska lodowe? Odpowiedź na to pytanie wydaje się z pozoru oczywista. Przekształcenia antropogeniczne mają równie istotny wpływ na przebieg i charakter zjawisk lodowych na rzece. Jednym z przykładów takiej działalności może być regulacja koryta rzecznego. Poprzez uregulowanie koryta udrażnia się przepływ kry i ogranicza tworzenie się zatorów lub pokrywy lodowej na rzece, przez co minimalizuje się ryzyko wystapienia powodzi. Przekształcenia natury antropogenicznej, takie jak: zabudowa hydrotechniczna, konfiguracja koryta, istnienie stopni wodnych, zapór i zbiorników w biegu rzeki, zrzuty wód podgrzanych, zasolonych lub zanieczyszczonych w inny sposób, mają równie istotny, jak nie większy wpływ na tworzenie się i przebieg zjawisk lodowych na rzece. Wszystkie te elementy mają wpływ na charakterystykę termiczną wód, a więc i na tempo ich zamarzania (Gorączko i Pawłowski, 2014). Wymienione czynniki mogą zatem przyspieszać i wydłużać czas trwania zlodzenia rzeki lub ograniczać jego rozwój, a w skrajnych wypadkach nawet nie dopuszczać do jego zainicjowania. Antropopresja i stopień zurbanizowania zlewni albo jej fragmentu może powodować, że rzeki sąsiednich zlewni będą znacznie różnić się ustrojem lodowym. W ramach jednej rzeki może wystąpić bardzo zróżnicowany przebieg zjawisk lodowych w jej górnym, środkowym i dolnym biegu.

Szeroki zakres oddziaływania zjawisk lodowych stał się tematem wielu prac badawczych. Początkowe prace miały charakter czysto poznawczy i dotyczyły form i typów genetycznych lodu rzecznego oraz sposobu jego powstawania. Badania w tym zakresie prowadzili: Dobrowolski (1923), Lambor (1948, 1959), Gołek (1957, 1964), Pasławski (1970) i Majewski (1987). Badania zjawisk lodowych z czasem stały się wieloaspektowe i znalazły zastosowanie praktyczne. Było to związane np. z ochrona przeciwpowodziową, szczególnie na odcinkach rzek silnie zagrożonych wystąpieniem powodzi zatorowych. W Polsce szczególne zainteresowanie problematyką zjawisk lodowych nastąpiło na przełomie lat 70. i 80. XX wieku. Dodatkowym powodem tego zainteresowania była katastrofalna powódź na Wiśle, która miała miejsce w styczniu 1982 roku w rejonie Płocka, a której główną przyczyną było wystąpienie na rzece zatoru lodowego (Grześ, 1991). Badania wpływu antropopresji na przebieg zjawisk lodowych na rzekach prowadzili m.in.: Wokroj (1954), Gołek (1957, 1964), Babiński (1985), Braniecki i Biegała (1985), Majewski (1985, 1987, 2009), Grześ (1991, 1999), Banach (1994, 2007), Pawłowski (2008a, 2008b), Pawłowski i Sobota (2012). Większość prac dotyczyła środkowego biegu Wisły, szczególnie obszaru znajdującego się w rejonie Jeziora Włocławskiego. Niektóre badania były prowadzone na innych rzekach np. na Warcie. Badania takie prowadziła Kornaś (2014) oraz Gorączko i Pawłowski (2014).

Nie bez znaczenia jest także rozpatrywanie problemu występowania zjawisk lodowych i ich potencjalnych skutków w skali regionalnej, ponieważ intensywność występowania danych zjawisk, jak np. powodzi zatorowych wywołanych zjawiskami lodowymi, jest związana przede wszystkim z lokalnymi uwarunkowaniami.

Podstawowym celem przeprowadzonych badań było wykazanie wpływu piętrzących obiektów hydrotechnicznych oraz zabudowy koryta rzecznego na przebieg i zmienność czasu trwania zjawisk lodowych występujących na rzekach oraz konsekwencji, jakie te zmiany za sobą niosą. Głównym celem pracy jest potwierdzenie hipotezy, że działalność antropogeniczna prowadzona w obrębie dolin rzecznych w znacznym stopniu może przyczynić się do zmiany czasu trwania i przebiegu zjawisk lodowych oraz rodzaju lodu występującego na rzekach. Dodatkowym istotnym elementem pracy jest przedstawienie przebiegu i zmienności zjawisk na tle zmian klimatycznych zachodzących w strefie brzegowej Bałtyku, przy uwzględnieniu przebiegu oscylacji północnoatlantyckiej (NAO) i zmian temperatury powietrza, jako głównego czynnika wpływającego na czas trwania i formę lodu występującą na rzekach. 
Łukaszewicz, J.T. (2017). Przebieg i charakter zjawisk lodowych na wybranych odcinkach rzek Przymorza o wysokim stopniu antropopresji na tle zmian klimatycznych zachodzących w strefie brzegowej Bałtyku. Acta Sci. Pol. Architectura, 16 (1), 93-113. doi: 10.22630/ASPA.2017.16.1.09.

\section{OBSZAR BADAŃ}

Obszar badań obejmuje swoim zasięgiem zlewnie trzech rzek przymorskich: Słupi, Łupawy i Łeby. Rzeki te są ciekami I rzędu. Od północy graniczą z wybrzeżem Bałtyku (rys. 1). Źródła rzek znajdują się na Pojezierzu Kaszubskim. Wszystkie omawiane w pracy rzeki zaliczane są do rzek małych, tzn. takich, których długość nie przekracza $200 \mathrm{~km}$, a powierzchnia dorzecza $10000 \mathrm{~km}^{2}$ - tabela 1 (Gerstmannowa, Florek i Konarski, 2001).

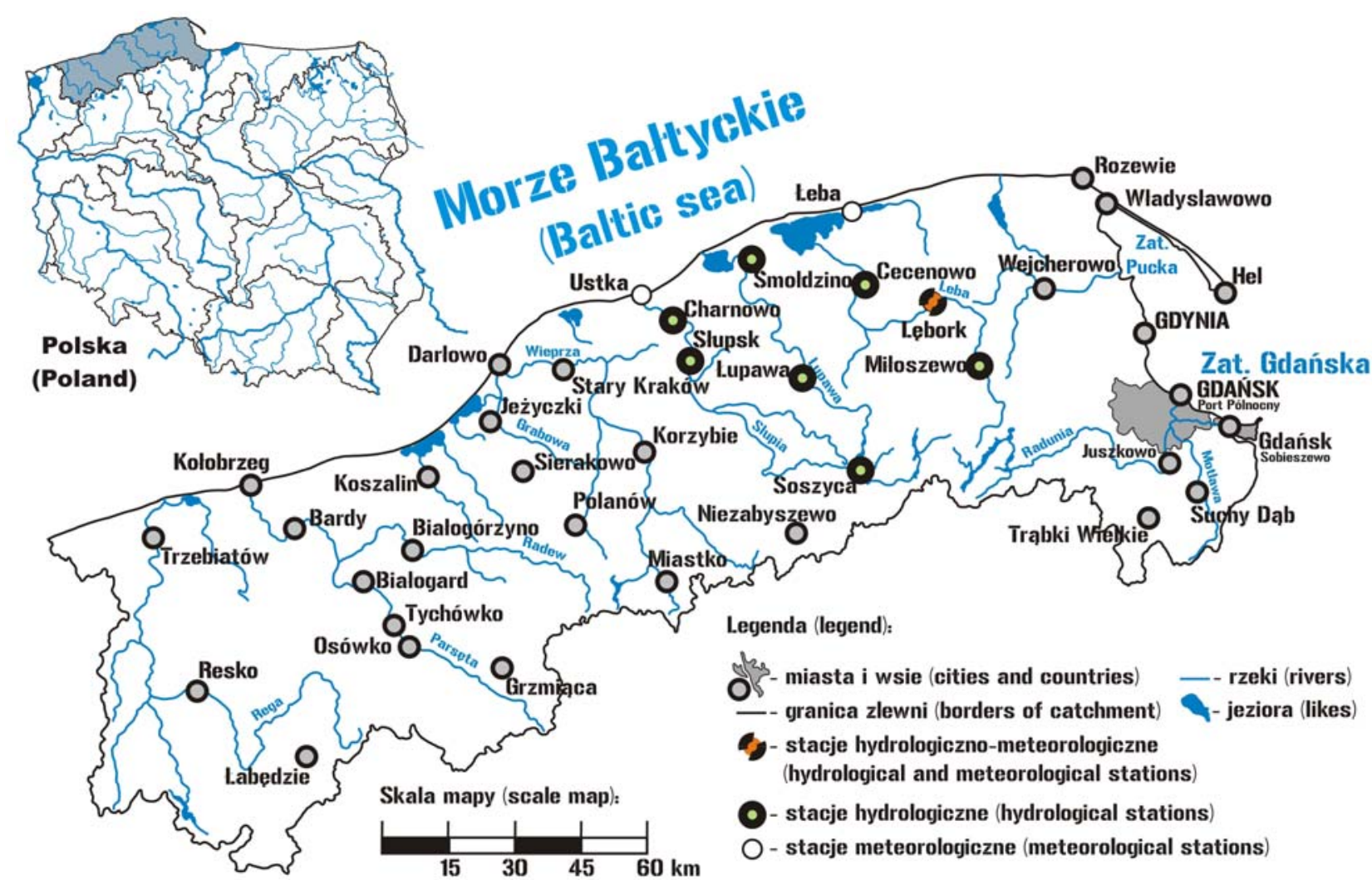

Rys. 1. Rozmieszczenie stacji pomiarowych IMGW na tle mapy podziału hydrograficznego Polski (region Przymorze)

Fig. 1. Location of IMGW measuring stations in relation to the map of the hydrographic distribution in Poland (Region called Przymorze)

Tabela 1. Charakterystyczne parametry morfometryczne wybranych rzek Przymorza

Table 1. Characteristic morphometric parameters of the selected coastal rivers

\begin{tabular}{lcc}
\hline $\begin{array}{l}\text { Rzeka } \\
\text { River }\end{array}$ & $\begin{array}{c}\text { Długość rzeki }[\mathrm{km}] \\
\text { Length of the river }[\mathrm{km}]\end{array}$ & $\begin{array}{c}\text { Powierzchnia zlewni }\left[\mathrm{km}^{2}\right] \\
\text { Catch ment area }\left[\mathrm{km}^{2}\right]\end{array}$ \\
\hline Slupia & 138,6 & 1310,0 \\
Lupawa & 98,7 & 924,5 \\
Leba & 117,0 & 1801,2 \\
\hline
\end{tabular}


Łukaszewicz, J.T. (2017). Przebieg i charakter zjawisk lodowych na wybranych odcinkach rzek Przymorza o wysokim stopniu antropopresji na tle zmian klimatycznych zachodzących w strefie brzegowej Bałtyku. Acta Sci. Pol. Architectura, 16 (1), $93-113$. doi: 10.22630/ASPA.2017.16.1.09.

Rzeki te charakteryzują się różnym stopniem antropopresji. Niektóre odcinki, szczególnie w środkowym biegu rzek, znajdują się w obszarach zurbanizowanych na terenach miast, inne natomiast - w naturalnych, nieprzekształconych w żaden sposób działalnością antropogeniczną. Szczególnie widoczne jest to na rzece Łupawie i Łebie, które w swoim dolnym biegu przepływają przez teren Słowińskiego Parku Narodowego. Rzeka Słupia w swoim górnym biegu przepływa przez szereg jezior, wśród których można wymienić m.in.: Tuchlińskie, Pręgożyno, Krzynia, Trzebocińskie, Gowidlińskie, Węgorzyno i Żukowskie. Niektóre z tych jezior są wytworzone sztucznie, np. zbiornik w Krzyni. Łupawa w swoim dolnym biegu przepływa przez jezioro Gardno (Gerstmannowa i in., 2001).

Według podziału Polski na regiony fizycznogeograficzne, obszar badań znajduje się w makroregionie Pobrzeża Południowobałtyckiego i Pojezierza Południowobałtyckiego (Kondracki, 2009). Rzeki w swoim górnym biegu znajdują się w granicy makroregionu Pojezierzy Południowobałtyckich, natomiast w swoim środkowym i dolnym biegu - w makroregionie Pobrzeży Południowobałtyckich.

Na przebieg temperatury powierza w tym rejonie silny wpływ ma Morze Bałtyckie (Okołowicz i Martyn, 1984). W podziale Polski na regiony klimatyczne badany obszar mieści się w strefie klimatu bałtyckiego (Romer, 1949). Zimy w tym regionie są mniej mroźne niż w pozostałej części kraju (Woś, 1996).

\section{MATERIAt I METODY}

Analiza częstości i charakterystyka przebiegu oraz zmienności występowania zjawisk lodowych na wybranych odcinkach rzek Przymorza została opracowana na osnowie danych z 7 posterunków wodowskazowych i 3 stacji meteorologicznych Instytutu Meteorologii i Gospodarki Wodnej - Państwowego Instytutu Badawczego (rys. 1). Baza danych wykorzystanych w pracy zwiera podział zjawisk lodowych na poszczególne formy, do których można wliczyć: śryż, krę, lód brzegowy, pokrywę lodową, zator lodowy i zator śryżowy, a także podział szczegółowy, w którym uwzględniono dni, w jakich niektóre z wyżej wymienionych form wystąpiły jednocześnie, np. lód brzegowy i śryż, lód brzegowy i kra czy też śryż i kra. W pracy wykorzystano także dane meteorologiczne, zawierające średnie dobowe wartości temperatury powietrza ze stacji w Lęborku, Ustce i Łebie, które są najbliżej położonymi stacjami meteorologicznymi od miejsca prowadzenia obserwacji na posterunkach wodowskazowych wybranych rzek (Słupi, Łeby i Łupawy). Zmienność temperatury powietrza jest w sposób szczególny uzależniona od przebiegu cyrkulacji atmosferycznej, dlatego w pracy wykorzystano dane dotyczące przebiegu i zmienności wskaźnika oscylacji północnoatlantyckiej (NAO), wykorzystując do tego indeks Jonesa, który obliczany jest jako różnica ciśnienia atmosferycznego między Gibraltarem a południowo-zachodnią Islandią (Niedźwiedź, 2002). Wykorzystanie indeksu pomogło określić zmienność procentową występowania poszczególnych faz (NAO), co ma bezpośredni wpływ na zmienność temperatury powietrza.

Głównym celem pracy było przedstawienie zmian częstości, przebiegu oraz czasu trwania i typu zjawisk lodowych, przy uwzględnieniu wpływu antropopresji, co zostało poruszone we wstępie pracy, ale uwzględniono także aspekt zmian klimatycznych, ze szczególnym wyróżnieniem zmian temperatury powietrza.

W pracy zostały wykorzystane metody statystyczne i matematyczne. W celu przedstawienia częstości występowania zjawisk lodowych na rzekach zostały wyliczone sumy rocznej liczby dni z zaobserwowanym zjawiskiem lodowym na rzekach w półroczu chłodnym roku hydrologicznego. Zostały wyliczone także średnie arytmetyczne wartości temperatury dla poszczególnych lat i miesięcy okresu zimowego (zima meteorologiczna), a także wybranych miesięcy chłodnego półrocza roku hydrologicznego (temperatura od listopada do marca). Obliczenia zostały wykonane na podstawie średnich dobowych wartości temperatury powietrza. W pracy wyznaczono także współczynnik trendu liniowego dla zmian temperatury powietrza w wybranych miesiącach okresu chłodnego oraz współczynnik korelacji między temperaturą powietrza i temperaturą wody a wskaźnikiem oscylacji północnoatlantyckiej. Za pomocą wybranych metod statystycznych udało się 
Łukaszewicz, J.T. (2017). Przebieg i charakter zjawisk lodowych na wybranych odcinkach rzek Przymorza o wysokim stopniu antropopresji na tle zmian klimatycznych zachodzących w strefie brzegowej Bałtyku. Acta Sci. Pol. Architectura, 16 (1), 93-113. doi: 10.22630/ASPA.2017.16.1.09.

wydzielić najdłuższe okresy występowania zjawisk lodowych oraz tendencje i trendy zachodzące w zmianie występowania tych zjawisk na tle zmian klimatycznych i zmian temperatury.

W pracy podjęto także próbę określenia wpływu antropopresji na przebieg zjawisk na rzekach poprzez porównanie liczby dni, w których występowały określone zjawiska na odcinkach rzek o charakterze naturalnym (np. posterunek w Cecenowie) i odcinkach znajdujących sie w obszarze zabudowanym, poddanych antropopresji (np. w Słupsku, Lęborku). Podjęto także próbę określenia wpływu przepływu rzecznego, a także temperatury powietrza i wody na kształtowanie i zmienność przebiegu zjawisk lodowych na rzekach poprzez wyliczenie wskaźnika korelacji metodą Spearmanna i zastosowanie testów nieparametrycznych, które miały na celu określenie statystycznych różnic pomiędzy zmierzonymi parametrami w okresie wystapienia zjawisk lodowych i ich braku. Test Kruskala-Wallisa, jaki wykorzystano w pracy, posłużył do zbadania istotności statystycznej między liczbą dni, w których wystapiły zjawiska, a przepływem i temperaturą wody i powietrza. Test Manna-Kendalla-Saeyersa miał na celu uchwycenie punktu przełamania trendu w przepływie. W celu przeprowadzenia testów użyto bezpłatnego oprogramowania $\mathrm{R}$.

\section{WYNIKI}

Przeprowadzone badania pokazały, że zaobserwowanie trendów na obszarze wybranych zlewni jest utrudnione ze względu na duży wpływ Morza Bałtyckiego, które w znacznym stopniu determinuje roczny przebieg temperatury powietrza, szczególnie poprzez zmniejszenie wartości rocznych oraz miesięcznych amplitud oraz wahań rozkładu temperatury, głównie w okresie zimowym (Woś, 1999). Termiczne oddziaływanie Morza Bałtyckiego ma także wpływ na wydłużenie oraz przesunięcie się okresów trwania przejściowych pór roku. W strefie brzegowej zima i lato trwają stosunkowo krótko. $Z$ tego powodu notuje się wolniejszy spadek temperatury powietrza (Baranowski, 2008a, 2008b). Przeprowadzone badania wykazały, że warunki termiczne oraz zmiany temperatury powietrza w okresie zimowym uzależnione są przede wszystkim od charakteru cyrkulacji atmosferycznej i napływu mas powietrza z północnej części Oceanu Atlantyckiego (Girjatowicz, Świątek i Olechwir, 2002). W latach 1951-2010 w sezonie zimowym faza dodatnia oscylacji północnoatlantyckiej występowała częściej (57,6\%) niż faza ujemna (42,4\%). Biorąc pod uwagę miesiące zimowe, faza dodatnia najczęściej występowała w styczniu $(64,4 \%)$, a następnie w lutym $(64,0 \%)$, natomiast w grudniu częściej obserwowano fazę ujemną (50,8\%). Jednak różnica między fazami w tym miesiącu była zdecydowanie mniejsza niż w pozostałych miesiącach okresu zimowego. W badaniach uwzględniono także miesiące okresu chłodnego w roku hydrologicznym, czyli listopad i marzec. W listopadzie także zaobserwowano dominację fazy ujemnej nad fazą dodatnią (54,0\%), podobnie jak w przypadku grudnia, natomiast w marcu zaobserwowano wyraźną przewagę fazy pozytywnej (62,0\%) nad negatywną (rys. 2 i 3 ).

W badaniach wykazano także, że istnieje duża zgodność pomiędzy fazami NAO i zmianami temperatury powietrza (wzrost temperatury odpowiadający pozytywnej fazie i spadek temperatury odpowiadający negatywnej fazie). Potwierdza to wskaźnik korelacji pomiędzy wskaźnikiem NAO a temperaturą powietrza, wynoszący 0,73.

Badania wykazały wyraźny wzrost indeksu Jonesa, a zatem i wzrost pozytywnej fazy oscylacji północnoatlantyckiej w dwóch ostatnich dekadach okresu obserwacji. Szczególnie wyraźny trend dodatni zaobserwowano w styczniu i lutym (rys. 3). Dominacja fazy pozytywnej nad negatywną, wpływająca na wzrost temperatury, spowodowała skrócenie okresu występowania zjawisk lodowych na rzekach, a w skrajnych miesiącach okresu chłodnego - ich całkowity zanik. W dwóch ostatnich dekadach nie obserwuje się praktycznie dni ze zjawiskiem lodowym w listopadzie i marcu. Test korelacji pokazał także, że istnieje istotna zależność pomiędzy zmiennością temperatury powietrza i wody w badanym okresie. Współczynnik korelacji wyniósł 0,52 dla stacji w Słupsku, 0,43 w Lęborku i 0,44 w Smołdzinie, przy uwzględnieniu przesunięcia fazowego między parametrami o 4 tygodnie. Zwiększenie lub zmniejszenie odstępu czasu między parametrami pogorszyło wyniki korelacji. Podobne rezultaty otrzymano, obliczając wskaźnik korelacji między temperaturą powietrza i wody a przepływem. 
Łukaszewicz, J.T. (2017). Przebieg i charakter zjawisk lodowych na wybranych odcinkach rzek Przymorza o wysokim stopniu antropopresji na tle zmian klimatycznych zachodzących w strefie brzegowej Bałtyku. Acta Sci. Pol. Architectura, 16 (1), 93-113. doi: 10.22630/ASPA.2017.16.1.09.

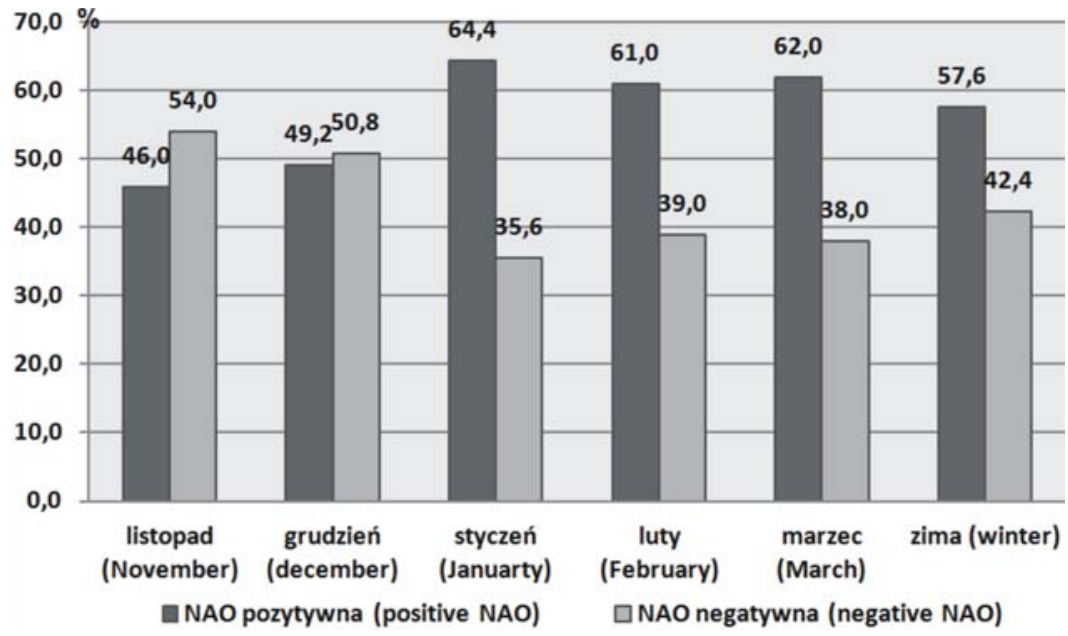

Rys. 2. Częstość [\%] występowania pozytywnej i negatywnej fazy NAO w miesiącach i sezonie zimowym w strefie brzegowej Bałtyku w latach 1951-2010

Fig. 2. The frequency [\%] occurrence the positive and negative phases of NAO during the months and winter in the coastal zone of the Baltic Sea in 1951-2010

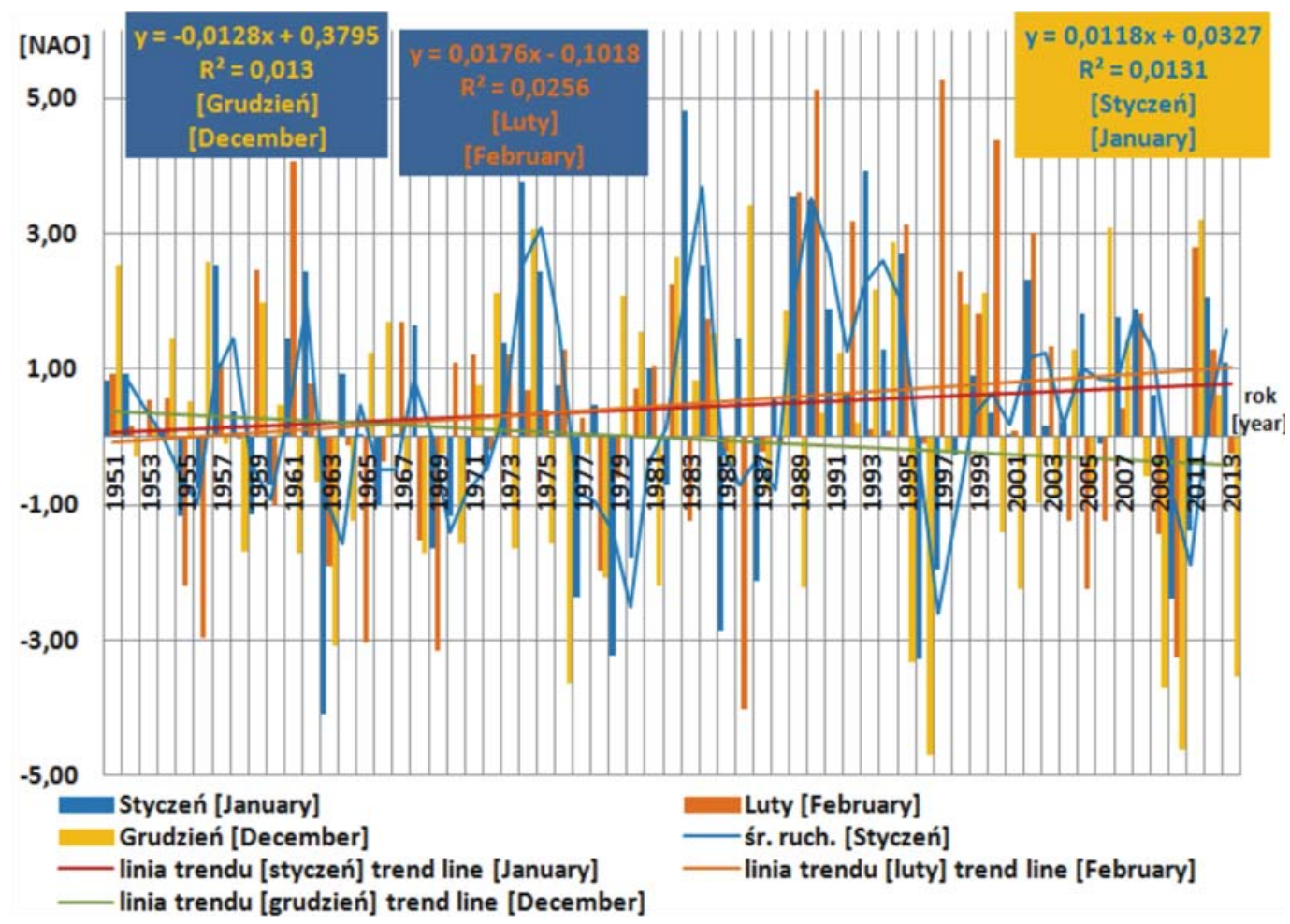

Rys. 3. Przebieg fazy dodatniej i ujemnej NAO w miesiącach sezonu zimowego w latach 1951-2010 z uwzględnieniem trendu liniowego dla poszczególnych miesięcy

Fig. 3. The course of the positive and negative NAO phase in winter months in 1951-2010 including a linear trend for each month 
Łukaszewicz, J.T. (2017). Przebieg i charakter zjawisk lodowych na wybranych odcinkach rzek Przymorza o wysokim stopniu antropopresji na tle zmian klimatycznych zachodzących w strefie brzegowej Bałtyku. Acta Sci. Pol. Architectura, 16 (1), 93-113. doi: 10.22630/ASPA.2017.16.1.09.

Na podstawie przeprowadzonych badań i analiz danych, uwzględniających wyniki ze wszystkich posterunków pomiarowych na rzekach, na których były prowadzone obserwacje zjawisk lodowych, można stwierdzić, że na rzece Łebie wystąpiła największa liczba dni z odnotowanym zjawiskiem lodowym. Najmniej zjawisk lodowych odnotowano na rzece Słupi (rys. 4).

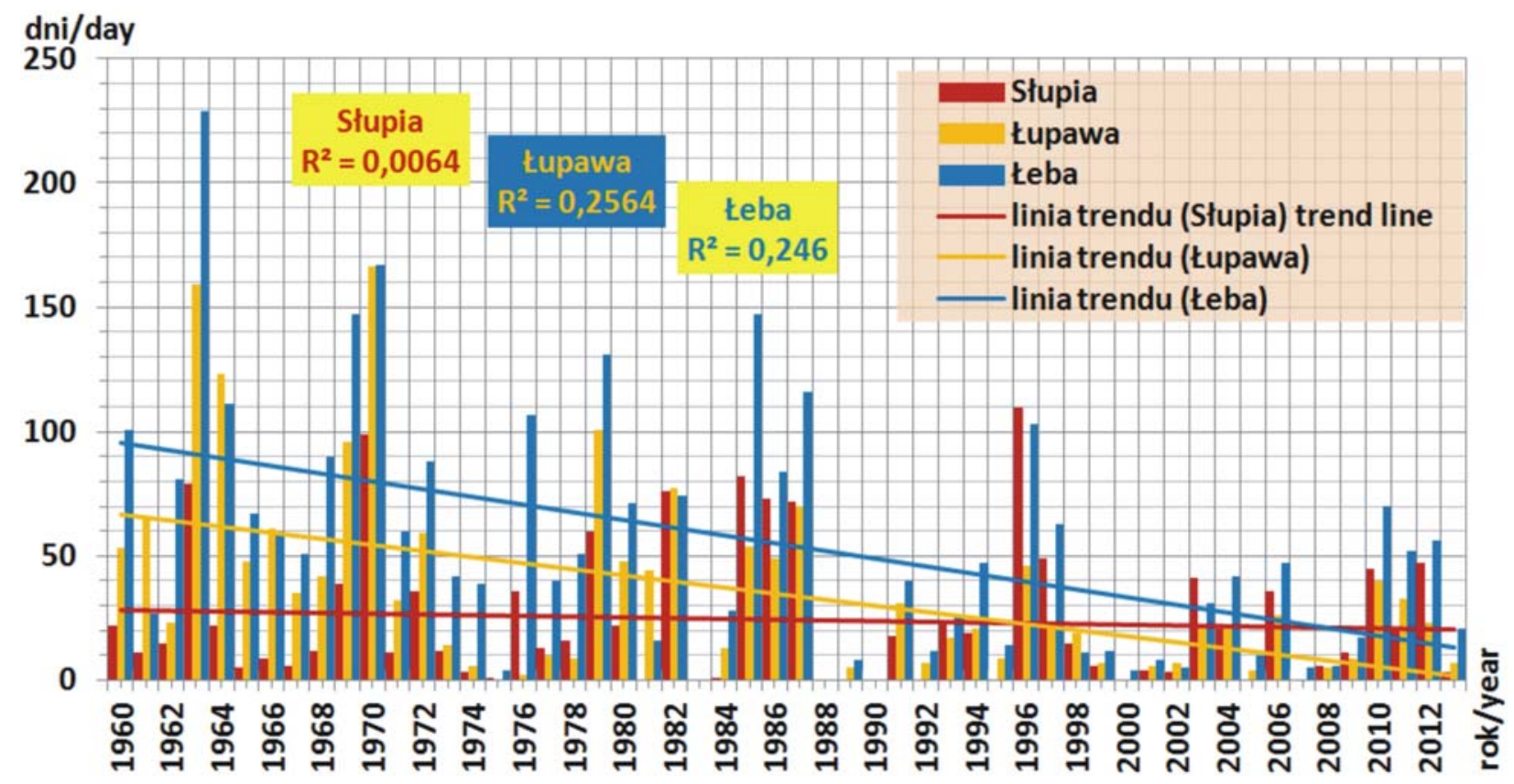

Rys. 4. Liczba dni ze zjawiskami lodowymi na rzekach Przymorza w latach 1960-2013

Fig. 4. The number of days with the ice phenomena on the rivers in 1960-2013

Główną przyczyną takiego rozkładu czasu trwania zjawisk była temperatura powierza (rys. 5 i 6). Stacja meteorologiczna położona w Ustce (rys. 1) cechuje się najwyższym średnim rocznym rozkładem temperatury dla okresu zimowego, a także dla półrocza chłodnego roku hydrologicznego, co bezpośrednio przekłada się na skrócenie liczby dni z odnotowanym zjawiskiem lodowym na Słupi.

Nie bez znaczenia pozostaje tu także aspekt działalności antropogenicznej. Przeprowadzone badania wyraźnie wskazują, jak duże znaczenie na czas trwania i typ genetyczny lodu występujący na rzece ma działalność antropogeniczna dotycząca w sposób szczególny zagospodarowania dwóch z trzech omawianych rzek. Łeba jest rzeką, która cechuje się najmniejszym stopniem ingerencji człowieka w jej koryto. Koryta rzek Słupi i Łupawy zostały uregulowane, a spadek terenu przyczynił się do budowy systemu hydroelektrowni i zbiorników wodnych. Działania te doprowadziły do zwiększenia prędkości przepływu na tych rzekach, co może powodować skrócenie czasu występowania zjawisk lodowych (rys. 7).

Im bardziej burzliwy przepływ, tym mniejsze prawdopodobieństwo wytworzenia się pokrywy lodowej na rzece, co znajduje swoje potwierdzenie w otrzymanych wynikach. Na rzece Słupi obserwuje się mniej dni z pokrywą lodową niż na rzece Łebie. Szczególnie widoczne jest to na stacji wodowskazowej w Słupsku, gdzie pokrywę lodową zaobserwowano tylko przez jeden dzień w całym 54-letnim okresie badań. Na tym odcinku rzeka jest uregulowana, stacja wodowskazowa znajduje się na terytorium miasta, a więc prędkość przepływu jest większa niż na pozostałych odcinkach (rys. 7), przez co dni z zaobserwowaną pokrywą lodową jest mniej. 


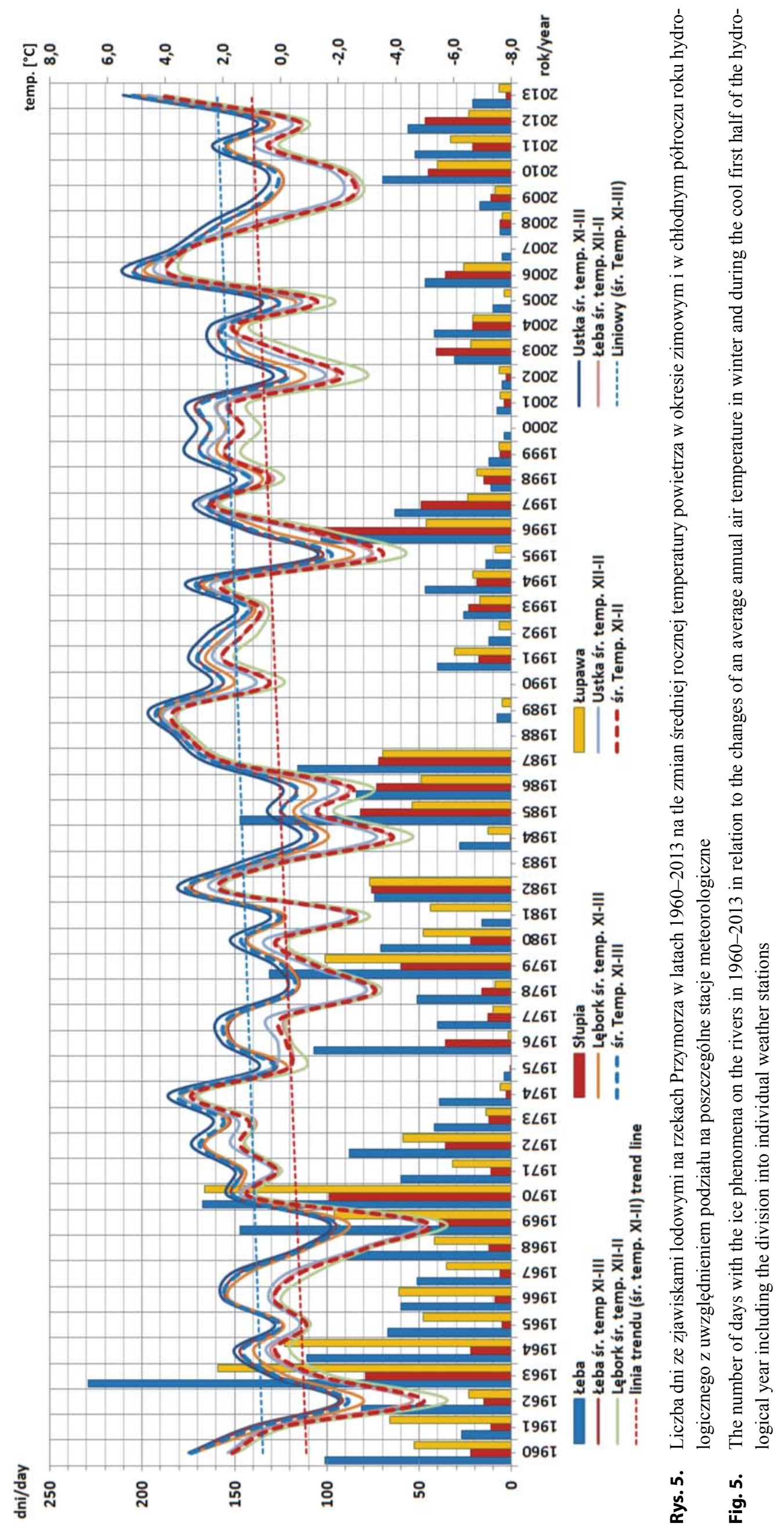




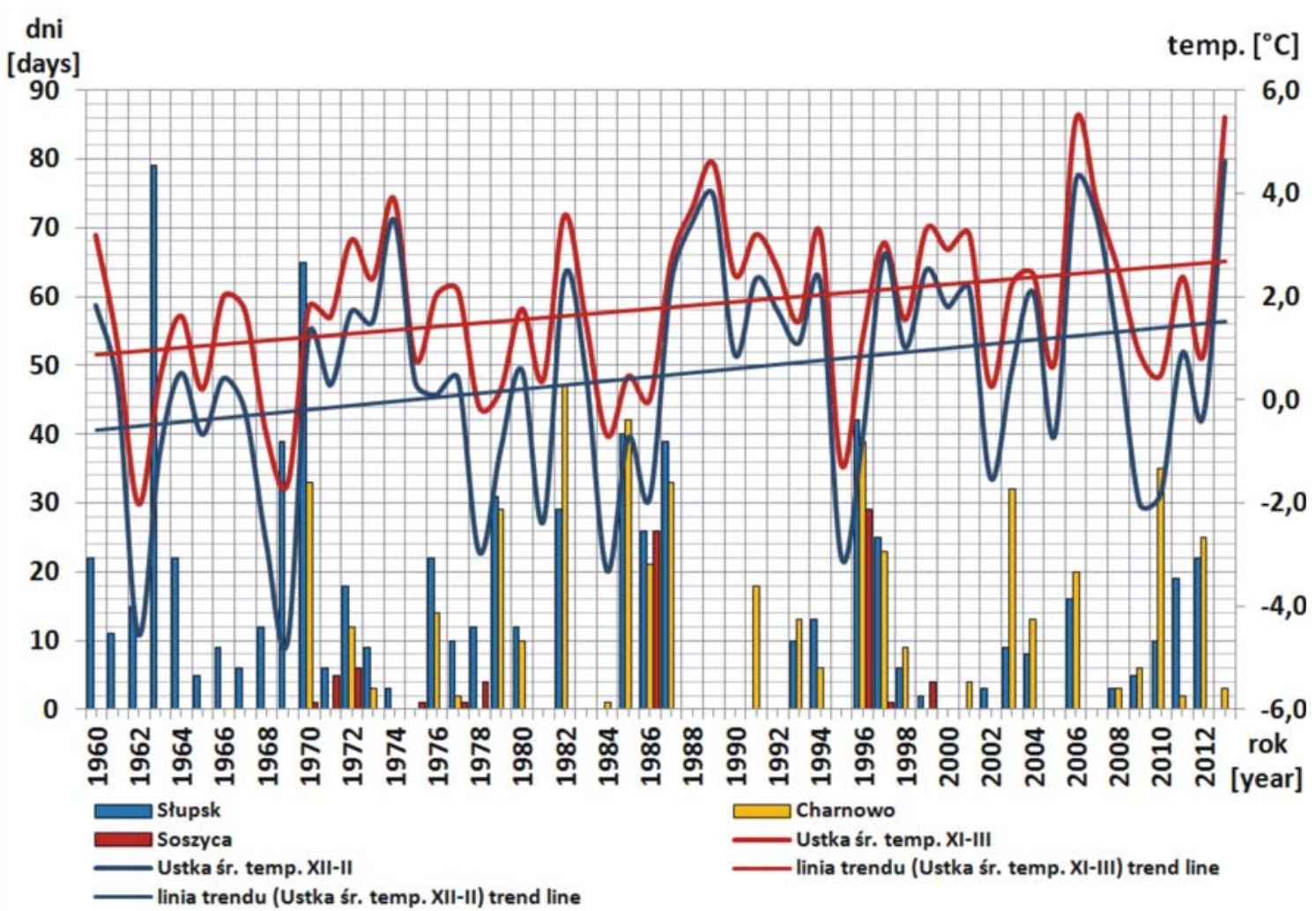

Rys. 6. Liczba dni ze zjawiskami lodowymi na rzece Słupi w latach 1960-2013 na tle zmian średniej rocznej temperatury powietrza w okresie zimowym i w chłodnym półroczu roku hydrologicznego w Ustce z uwzględnieniem podziału na poszczególne stacje wodowskazowe

Fig. 6. The number of days with the ice phenomena on the Słupia River in 1960-2013 in relation to the changes of an average annual air temperature in winter and during the cool first half of the hydrological year in Ustka including the division into individual water gauge stations

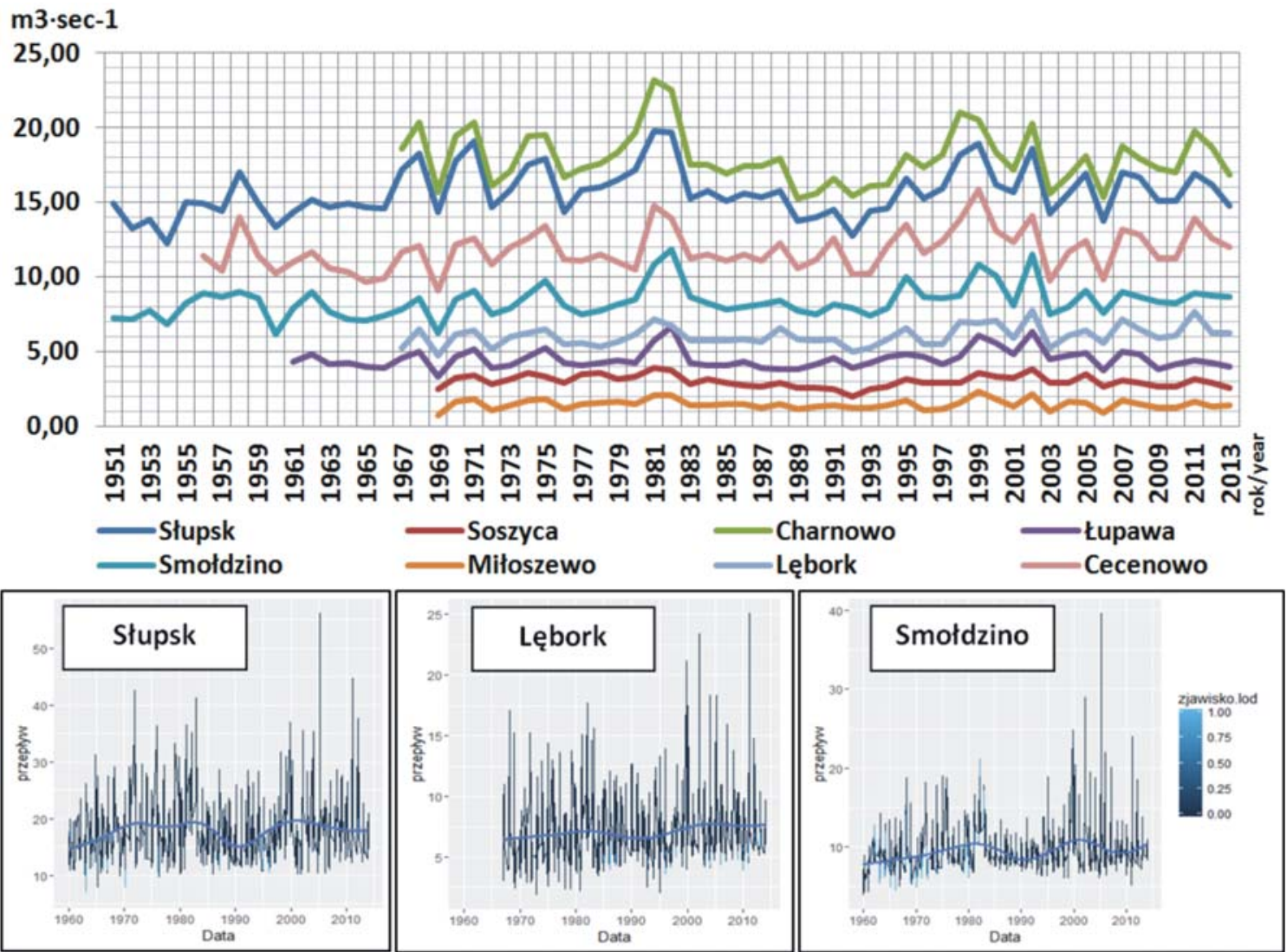

Rys. 7. Przepływ wody na wybranych posterunkach wodowskazowych rzek Przymorza i zależności między przepływem oraz temperaturą powietrza i wody na wybranych stacjach

Fig. 7. The water flow at selected gauges on the coastal rivers and the interdependence between the flow, the temperature of air and water at the selected stations 
Łukaszewicz, J.T. (2017). Przebieg i charakter zjawisk lodowych na wybranych odcinkach rzek Przymorza o wysokim stopniu antropopresji na tle zmian klimatycznych zachodzących w strefie brzegowej Bałtyku. Acta Sci. Pol. Architectura, 16 (1), 93-113. doi: 10.22630/ASPA.2017.16.1.09.

Niestety badanie korelacji między liczbą dni, w których wystąpiły zjawiska lodowe, a przepływem testem Kruskala-Wallisa nie wykazały istotnych zależności między tymi wskaźnikami. Zależność została zaobserwowana tylko w analizie liczby dni z zaobserwowanym zjawiskiem lodowym z prędkością przepływu na wybranych odcinkach rzek. Próba wyznaczenia trendu w przepływie metodą Manna-Kendalla-Saeyersa także nie wykazała istotnych zmian. Nie udało się w pełni uchwycić punktu przełamania trendu, aczkolwiek udało się wyznaczyć teoretyczne miejsce przełamania (rys. 7).

Kolejnym czynnikiem powodującym zmniejszoną liczbę dni z zaobserwowanym zjawiskiem lodowym na rzece mogą być zrzuty ścieków. Szczególnie widoczne jest to w obszarach miejskich, np. na stacji wodowskazowej w Słupsku, gdzie średnia roczna temperatura wód rzecznych jest większa niż w innych punktach, na których prowadzono obserwację (rys. 8). Temperatura ta przyczynia się do zmniejszenia liczby dni ze zjawiskami lodowymi na rzece (rys. 4 i 5). Test korelacji także tu nie wykazał istotnych zależności, wartość wskaźnika korelacji wyniosła $-0,02$. Zależności te mogłyby być bardziej widoczne dopiero przy uwzględnieniu przesunięcia czasowego.

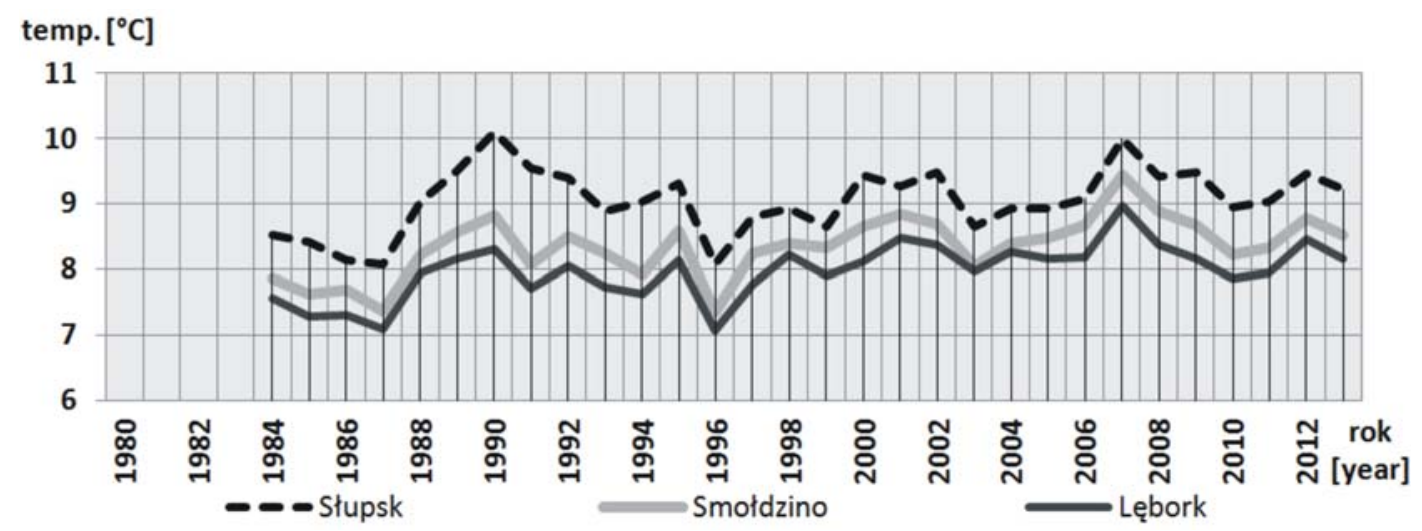

Rys. 8. Średnia roczna temperatura wód rzecznych na wybranych stacjach wodowskazowych

Fig. 8. The average annual temperature of the rivers' water at selected gauging stations

Rzeka Słupia jest rzeką uregulowaną, cechującą się największym wpływem antropopresji na tle innych analizowanych w tej pracy rzek. Naturalny charakter doliny rzeki Słupi został znacznie przekształcony w wyniku działalności antropogenicznej, związanej z regulacją koryta rzecznego w celu uzyskania energii wodnej. Regulacje przeprowadzone na rzece przyczyniły się do powstania w latach 1898-1926 zabudowy hydrotechnicznej składającej się z 4 zespołów: hydroelektrowni „Struga“ zlokalizowanej w miejscowości Soszyca, która jest jednym z najstarszych tego typu obiektów w Europie, elektrowni wodnej w Gałąźni Małej, największej z 4 wybudowanych na rzece, elektrowni Strzegomino powstałej w Konradowie oraz elektrowni Skarszów Dolny znajdującej się na rzece Skotawie, która jest jednym z dopływów rzeki Słupi (Gerstmannowa i Zalewski, 2001).

Rzeka na całej swojej długości została poddana przekształceniom, co doprowadziło nie tylko do zmiany jej biegu, ale także do zmiany jej długości oraz pierwotnego charakteru na wielu odcinkach. Koryto rzeki uległo przeniesieniu i skróceniu z 157,3 do 138,6 km. Główną przyczyną tak znacznego skrócenia było wybudowanie kanału doprowadzającego wody rzeki Słupi do Jeziora Głębokiego. Pierwotnie rzeka płynęła szerokim łukiem, omijając Jezioro Głębokie. Po wybudowaniu zapory na rzece Bytowej wody Słupi skierowano specjalnie wybudowanym kanałem przechodzącym przez teren o rzeźbie cechującej się znacznie większym spadkiem terenu (ponad 38,5 m) do jeziora. Woda spływająca tym kanałem umożliwiła budowę elektrowni wodnej w Gałąźni Małej, która osiąga moc $3500 \mathrm{~kW}$ - rysunek 1 (Gerstmannowa i Zalewski, 2001). 
Łukaszewicz, J.T. (2017). Przebieg i charakter zjawisk lodowych na wybranych odcinkach rzek Przymorza o wysokim stopniu antropopresji na tle zmian klimatycznych zachodzących w strefie brzegowej Bałtyku. Acta Sci. Pol. Architectura, 16 (1), 93-113. doi: 10.22630/ASPA.2017.16.1.09.

Przekształcenia prowadzące do tak znacznego skrócenia koryta były wynikiem nie tylko wcześniej opisanych, przeprowadzonych jeszcze przez inżynierów niemieckich prac związanych z budową systemu hydroenergetycznego, który przyczynił się do powstania zbiorników zaporowych, ale także prac regulacyjnych (Gerstmannowa i Zalewski, 2001). Prace regulacyjne w obrębie doliny objęły pogłębienie koryta, likwidację aż 50 zakoli, budowę jazów i kanałów. Najważniejsze prace przeprowadzono na południe od Słupska, a więc w środkowym i górnym biegu rzeki (rys. 1). Celowe działania przeprowadzone w obrębie doliny Słupi przyczyniły się do takiej modyfikacji, że odtworzenie pierwotnego charakteru rzeki stało się niemożliwe. Działania te mogły przyczynić się do znacznego skrócenia czasu trwania zjawisk lodowych na rzece. Znajduje to potwierdzenie w analizie porównawczej liczby dni ze zjawiskiem lodowym na rzece Słupi i Łebie oraz we wcześniej przeprowadzonych badaniach tego typu (np. 9 i 10). Podobne rezultaty otrzymali Gorączko i Pawłowski (2014), badając wpływ zbiornika Jeziorsko na przebieg i czas trwania zjawisk lodowych na Warcie w rejonie Uniejowa. Czas trwania zjawisk uległ znacznemu skróceniu poniżej zbiornika wodnego. Podobnie na rzece Słupi czas trwania zjawisk lodowych poniżej zbiornika zaporowego Krzynia i elektrowni w Gałąźni Małej znajdujących się powyżej stacji wodowskazowej w Słupsku czy też zbiornika wodnego Żukówko znajdującego się powyżej stacji wodowskazowej w Soszycy jest krótszy w porównaniu z danymi uzyskanymi na stacji w Charnowie (rys. 9, 11, 12 i 14-19).

Zbiorniki zaporowe zatrzymują rumowisko i zawiesinę, zaburzając $\mathrm{w}$ ten sposób naturalny charakter przepływu, co powoduje, że w dolnym biegu rzeki nie ma naturalnych jąder kondensacji sprzyjających tworzeniu się lodu (Gorączko i Pawłowski, 2014). Sergeevich (2009) wykazał, że w zależności od wielkości zbiornika wodnego ilość materiału rumowiskowego, a także ilość zawiesiny gromadzącej się powyżej zapory jest znacznie większa niż poniżej zapory. W przypadku średnich zbiorników akumulacja może sięgać nawet $65 \%$.

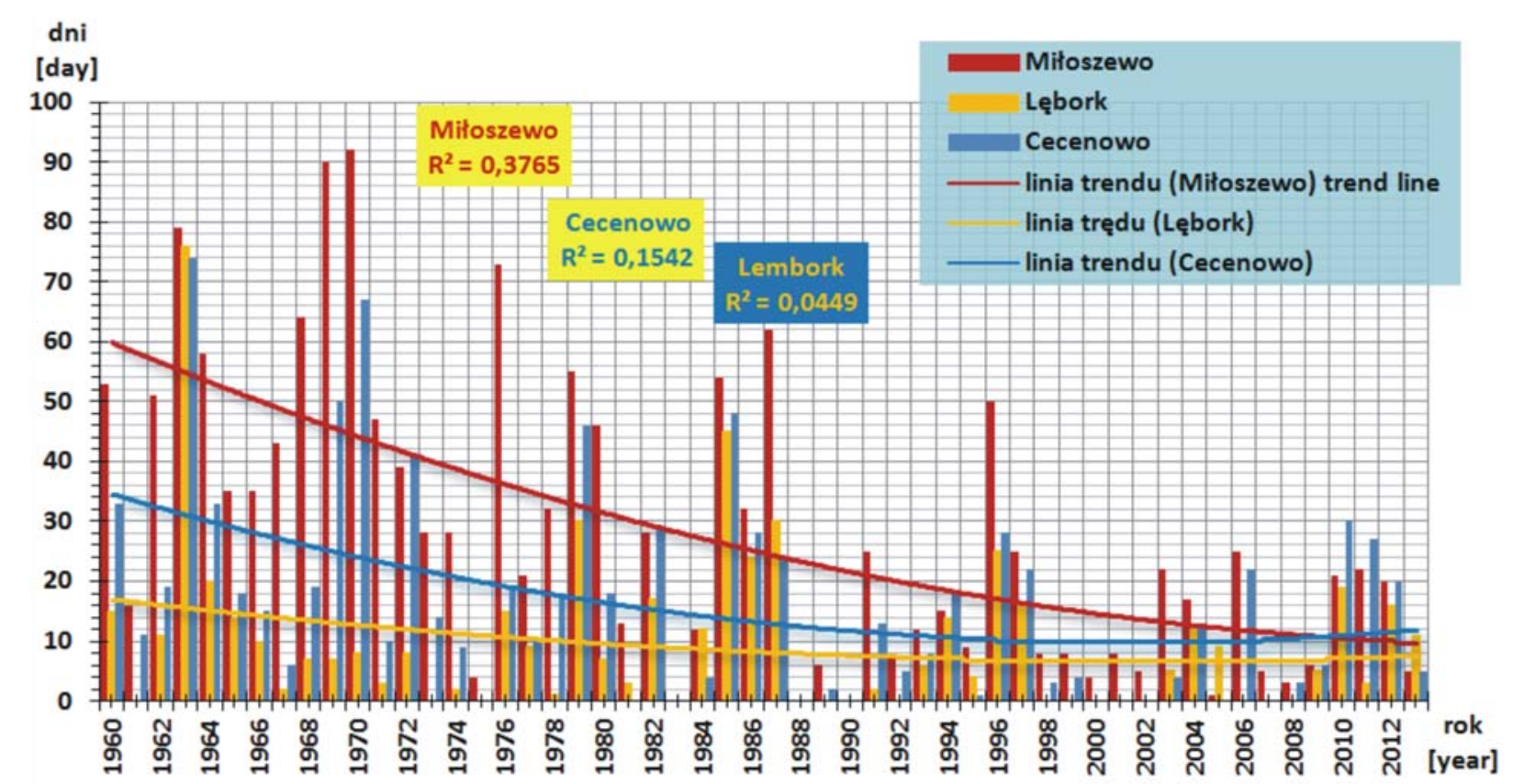

Rys. 9. Liczba dni ze zjawiskami lodowymi na rzece Łebie w latach 1960-2013 przy uwzględnieniu podziału na stacje wodowskazowe

Fig. 9. The number of days with the ice phenomena on the Leba River in 1960-2013 including the distribution of water gauge stations 


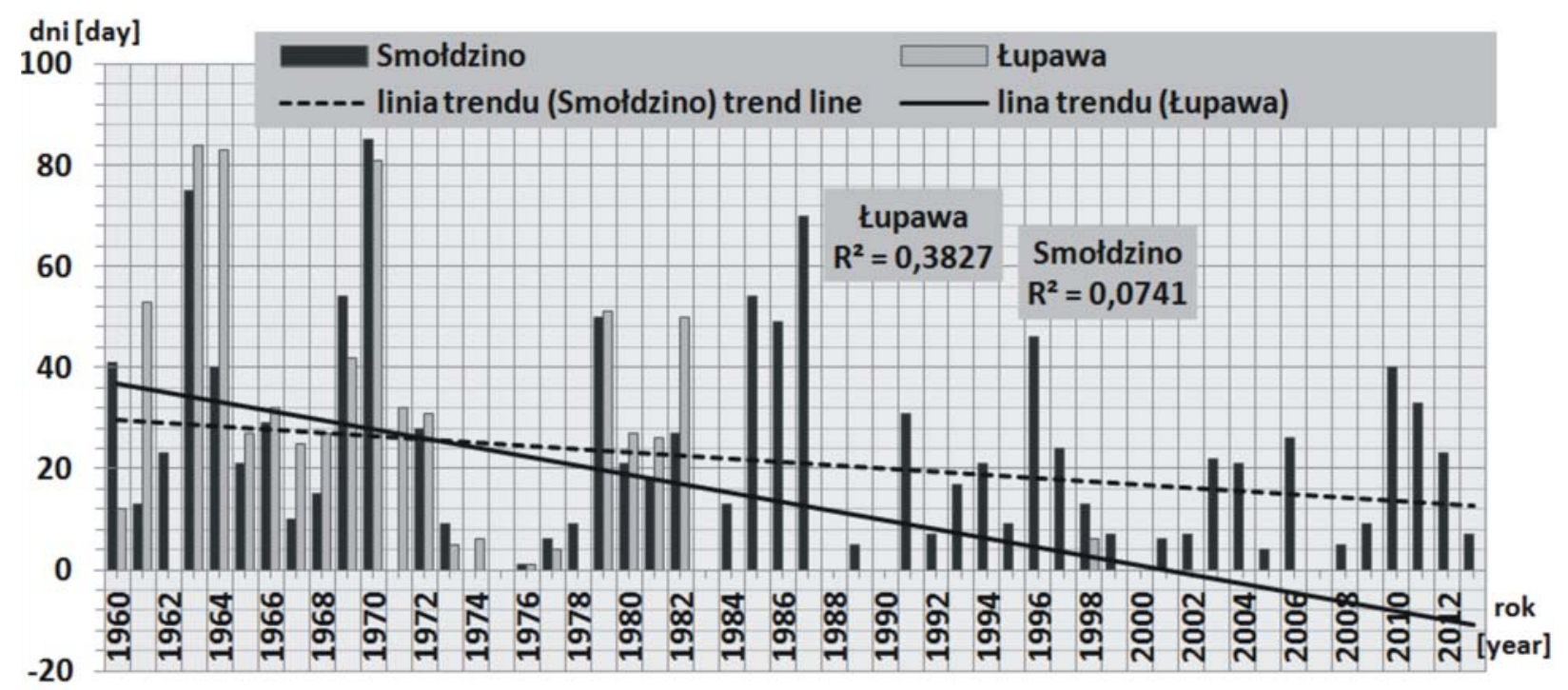

Rys. 10. Liczba dni ze zjawiskami lodowymi na rzece Łupawie w latach 1960-2013 przy uwzględnieniu podziału na stacje wodowskazowe

Fig. 10. The number of days with the ice phenomena on Łupawa River in 1960-2013 including the distribution of water gauge stations

Badania Sergeevicha (2009) wykazały także, że budowa zbiorników zaporowych na rzece skraca czas trwania zjawisk lodowych poniżej zapory. Wykazały też, że na odcinku rzeki poniżej zbiornika zaporowego średniej wielkości zjawiska lodowe pojawiają się aż od 4 do 9 dni później, a ustępują od 30 do 36 dni wcześniej niż w górnym biegu rzeki. Małe zbiorniki także mają wpływ na skrócenie czasu trwania dni ze zjawiskiem lodowym. Zjawiska te zanikają 18-30 dni wcześniej (Sergeevich, 2009).

Wyniki znajdują swoje potwierdzenie w niniejszej pracy. Podobne rezultaty otrzymano przy porównaniu przebiegu zjawisk lodowych i czasu ich trwania na rzece Łupawie, która także jest rzeką uregulowaną, ale w znacznie mniejszym stopniu niż Słupia. Zarówno na stacji wodowskazowej w Łupawie, jak i w Smołdzinie,

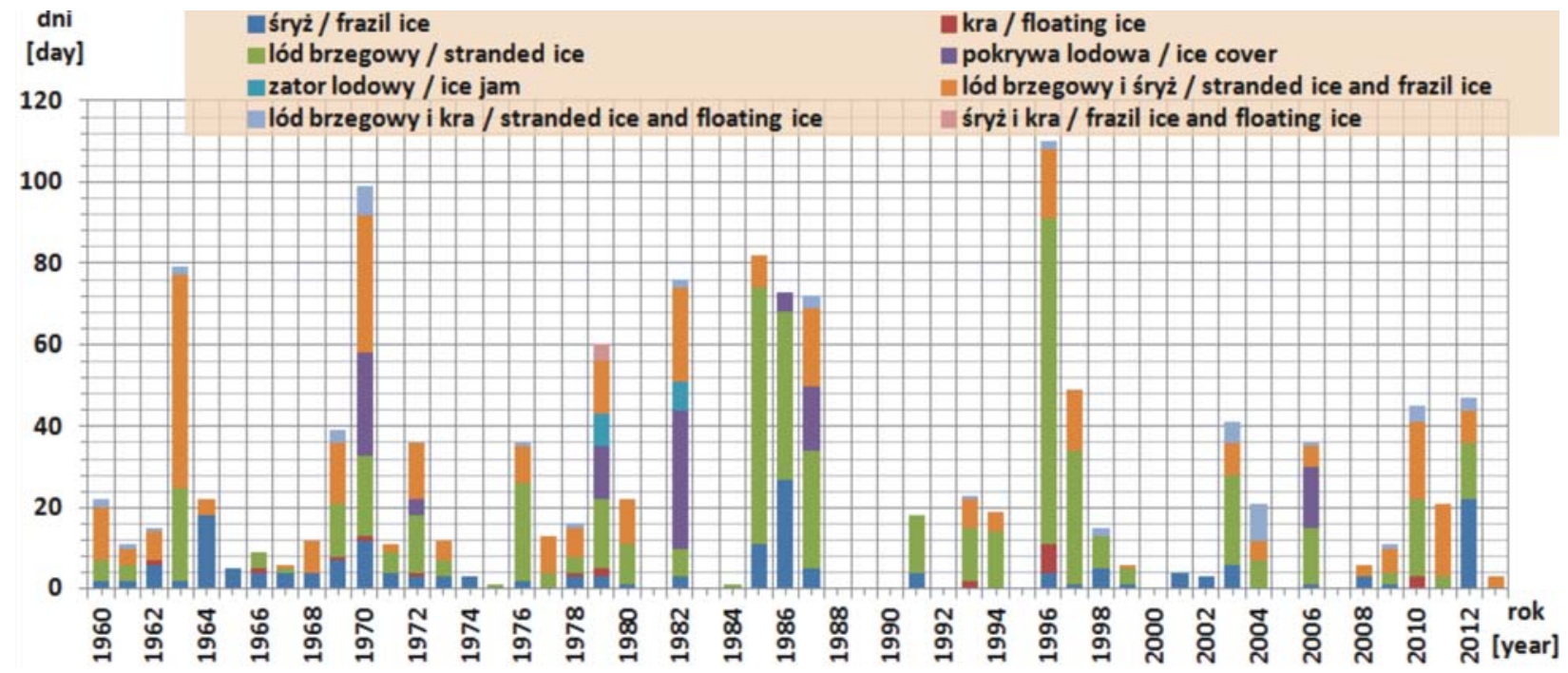

Rys. 11. Liczba dni z określonym typem zjawisk lodowych na rzece Słupi w latach 1960-2013

Fig. 11. The number of days with a certain type of ice phenomena on Stupia River in 1960-2013 
Łukaszewicz, J.T. (2017). Przebieg i charakter zjawisk lodowych na wybranych odcinkach rzek Przymorza o wysokim stopniu antropopresji na tle zmian klimatycznych zachodzących w strefie brzegowej Bałtyku. Acta Sci. Pol. Architectura, 16 (1), 93-113. doi: 10.22630/ASPA.2017.16.1.09.

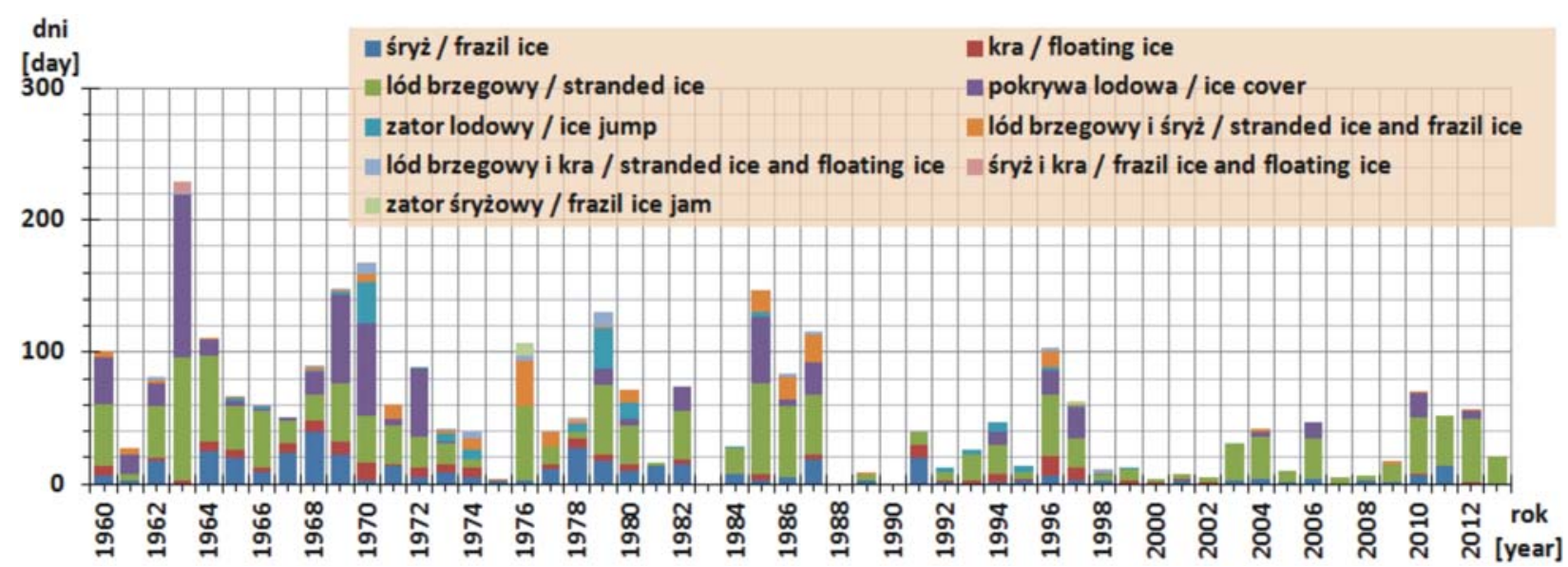

Rys. 12. Liczba dni z określonym typem zjawisk lodowych na rzece Łebie w latach 1960-2013

Fig. 12. The number of days with a certain type of ice phenomena on Łeba River in 1960-2013

które są położone poniżej hydroelektrowni, obserwuje się znacznie mniejszą liczbę dni ze zjawiskiem lodowym niż na rzece Łebie, która jest w najmniejszym stopniu przekształcona działalnością człowieka, szczególnie w swoim górnym i środkowym biegu (rys. 10, 13, 20, 21).

Na rzece Łupawie przy hydroelektrowniach nie utworzono zbiorników zaporowych, przez co przepływ rzeki zachował bardziej naturalny charakter, co przyczyniło się do tego, że występuje tu więcej dni ze zjawiskiem lodowym niż na rzece Słupi. Rzeka Łeba charakteryzuje się najmniejszym stopniem antropopresji, szczególnie widoczne jest to w jej dolnym biegu, gdzie rzeka przepływa przez teren Słowińskiego Parku Narodowego. Łeba jest jednym z dwóch badanych cieków, na którym wystąpiły wszystkie możliwe typy genetyczne lodu. Drugą rzeką, na której zaobserwowano wszystkie formy lodowe, jest Łupawa, jednakże liczba dni z poszczególnymi typami lodu na rzece Łupawie jest mniejsza (rys. 9-12).

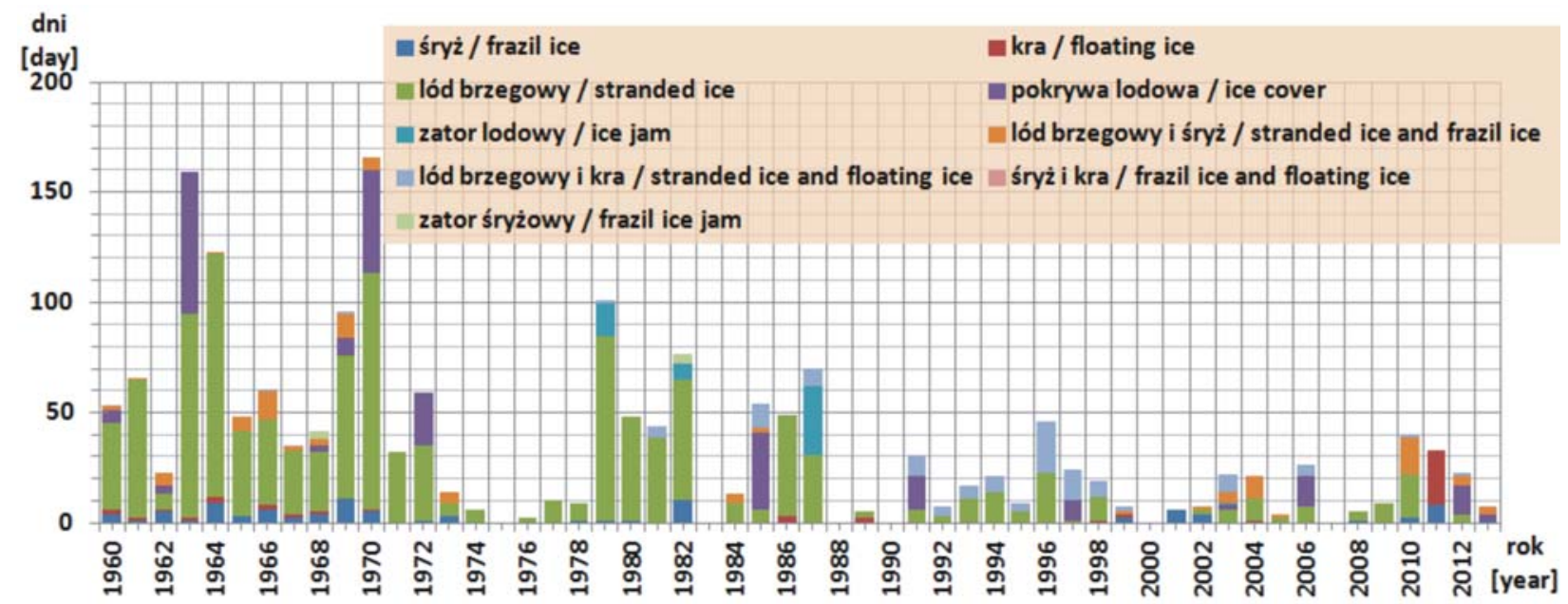

Rys. 13. Liczba dni z określonym typem zjawisk lodowych na rzece Łupawie w latach 1960-2013

Rys. 13. The number of days with a certain type of ice phenomena on Łupawa River in 1960-2013 
Łukaszewicz, J.T. (2017). Przebieg i charakter zjawisk lodowych na wybranych odcinkach rzek Przymorza o wysokim stopniu antropopresji na tle zmian klimatycznych zachodzących w strefie brzegowej Bałtyku. Acta Sci. Pol. Architectura, 16 (1), 93-113. doi: 10.22630/ASPA.2017.16.1.09.

Wyjątek stanowią dni, w których zaobserwowano jednoczesne wystąpienie lodu brzegowego i kry. W przypadku tego zjawiska odnotowano wyraźną przewagę w liczbie dni na rzece Łupawie (rys. 14-21). Na stacji w Charnowie (rys. 1) można zaobserwować 7 typów genetycznych lodu na rzece.

Każdy z obserwowanych typów lodu pojawia się niemal w każdej dekadzie badanego okresu (rys. 14-21). W Słupsku także zaobserwowano 7 typów lodu, ale liczba dni z formami takimi jak stała pokrywa lodowa na rzece jest znikoma. W całym okresie 1960-2013 pokrywę lodową zaobserwowano przez 1 dzień (rys. 18).

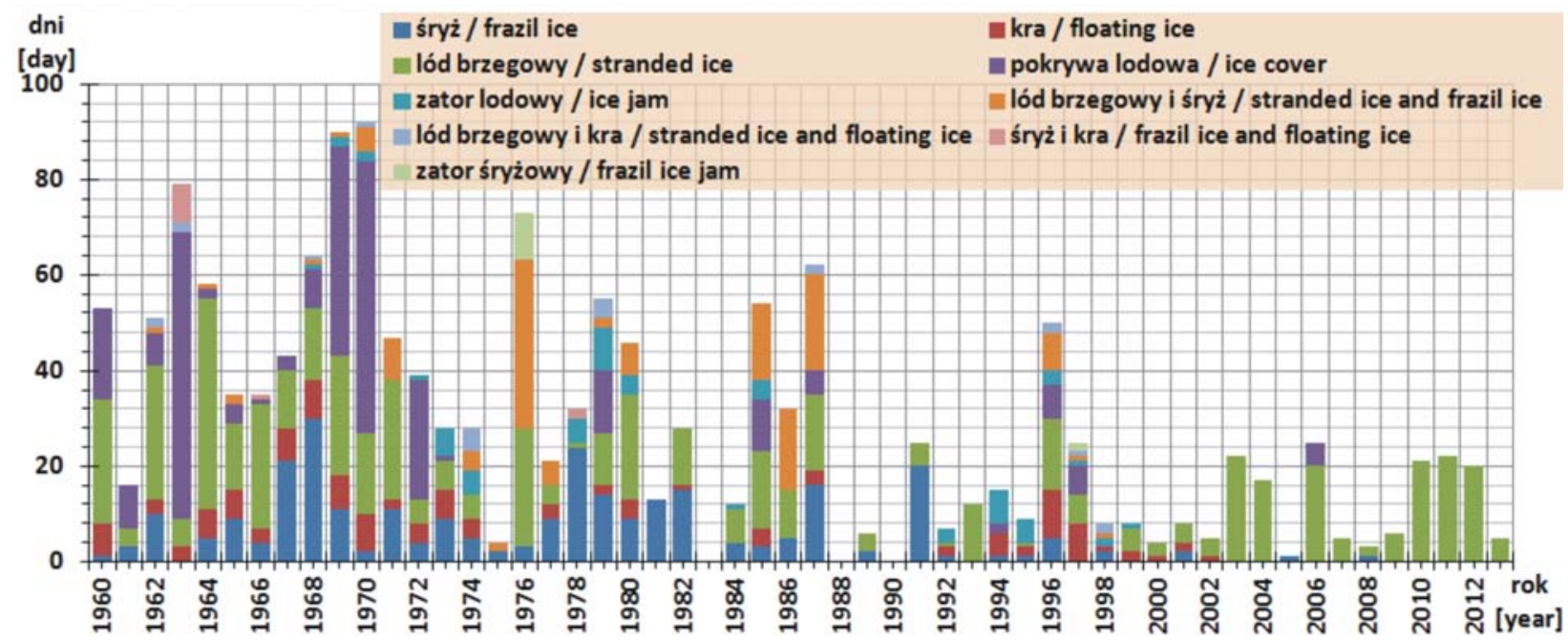

Rys. 14. Liczba dni z określonym typem zjawisk lodowych na rzece Łebie w latach 1960-2013. Stacja wodowskazowa w Miłoszewie

Fig. 14. The number of days with a certain type of ice phenomena on Łeba River in 1960-2013. The water gauge station in Miłoszewo

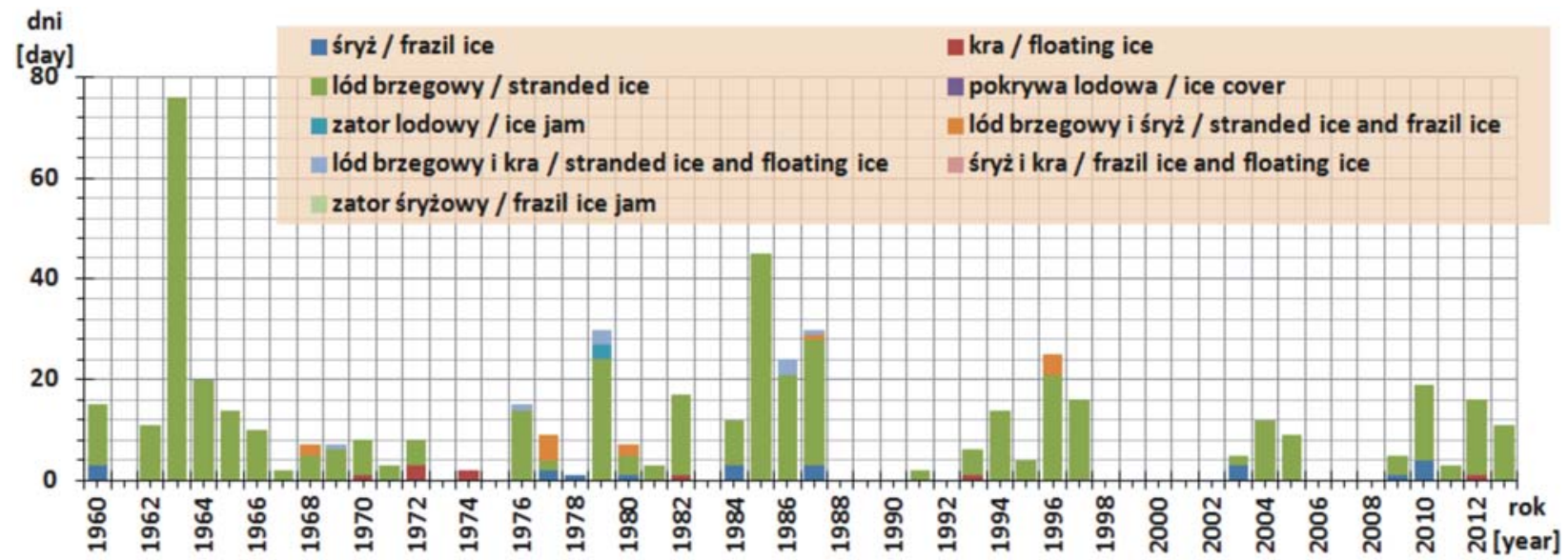

Rys. 15. Liczba dni z określonym typem zjawisk lodowych na rzece Łebie w latach 1960-2013. Stacja wodowskazowa w Lęborku

Fig. 15. The number of days with a certain type of ice phenomena on Łeba River in 1960-2013. The water gauge station in Lębork 
Łukaszewicz, J.T. (2017). Przebieg i charakter zjawisk lodowych na wybranych odcinkach rzek Przymorza o wysokim stopniu antropopresji na tle zmian klimatycznych zachodzących w strefie brzegowej Bałtyku. Acta Sci. Pol. Architectura, 16 (1), 93-113. doi: 10.22630/ASPA.2017.16.1.09.

Na stacji w Soszycy odnotowano tylko 2 typy lodu (rys. 17). Największą liczbę dni z poszczególnymi typami lodu na rzece odnotowano na Łebie, w jej górnym i dolnym biegu, na odcinku w Miłoszewie i Cecenowie (rys. 14 i 16).

Pierwszą przyczyną takiego rozkładu czasu trwania zjawisk jest temperatura powierza (rys. 4 i 5). Stacja meteorologiczna położona w Lęborku (rys. 1) cechuje się najmniejszym średnim rocznym rozkładem temperatury dla okresu zimowego, co bezpośrednio przekłada się na wydłużenie liczby dni z odnotowanym zjawiskiem lodowym na Łebie.

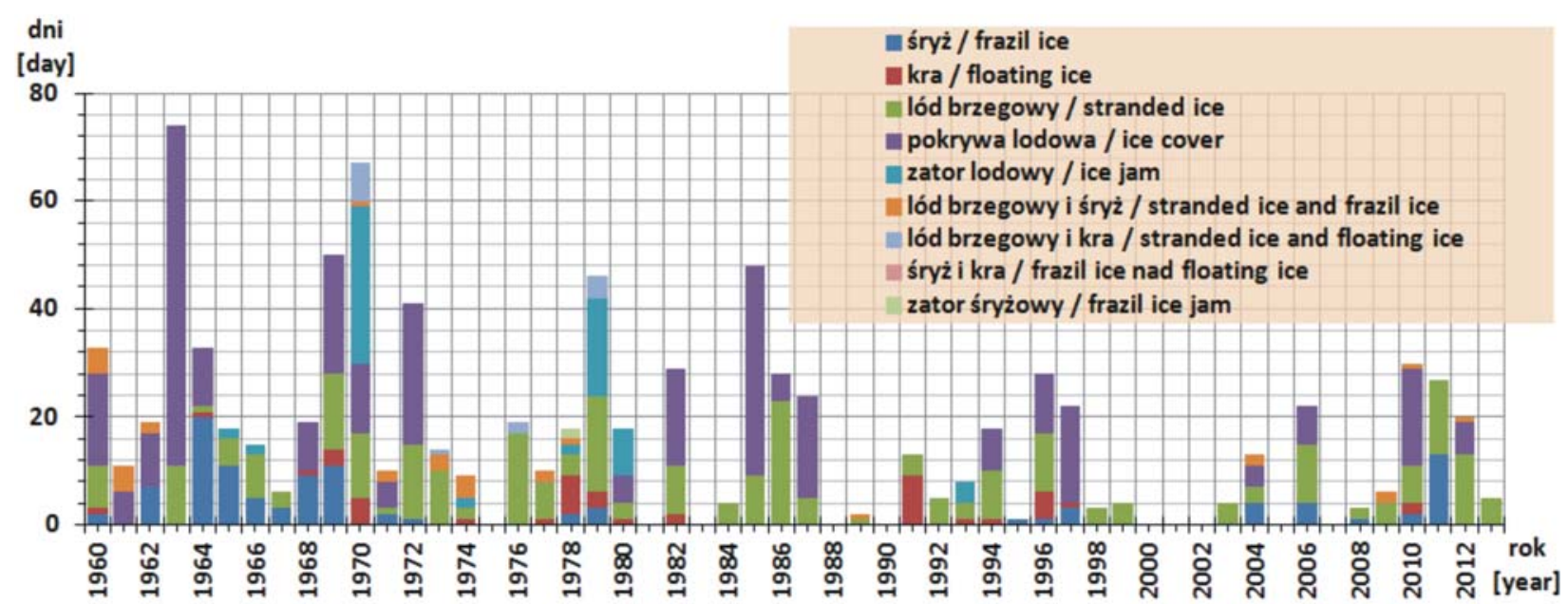

Rys. 16. Liczba dni z określonym typem zjawisk lodowych na rzece Łebie w latach 1960-2013. Stacja wodowskazowa w Cecenowie

Fig. 16. The number of days with a certain type of ice phenomena on Łeba River in 1960-2013. The water gauge station in Cecenowo

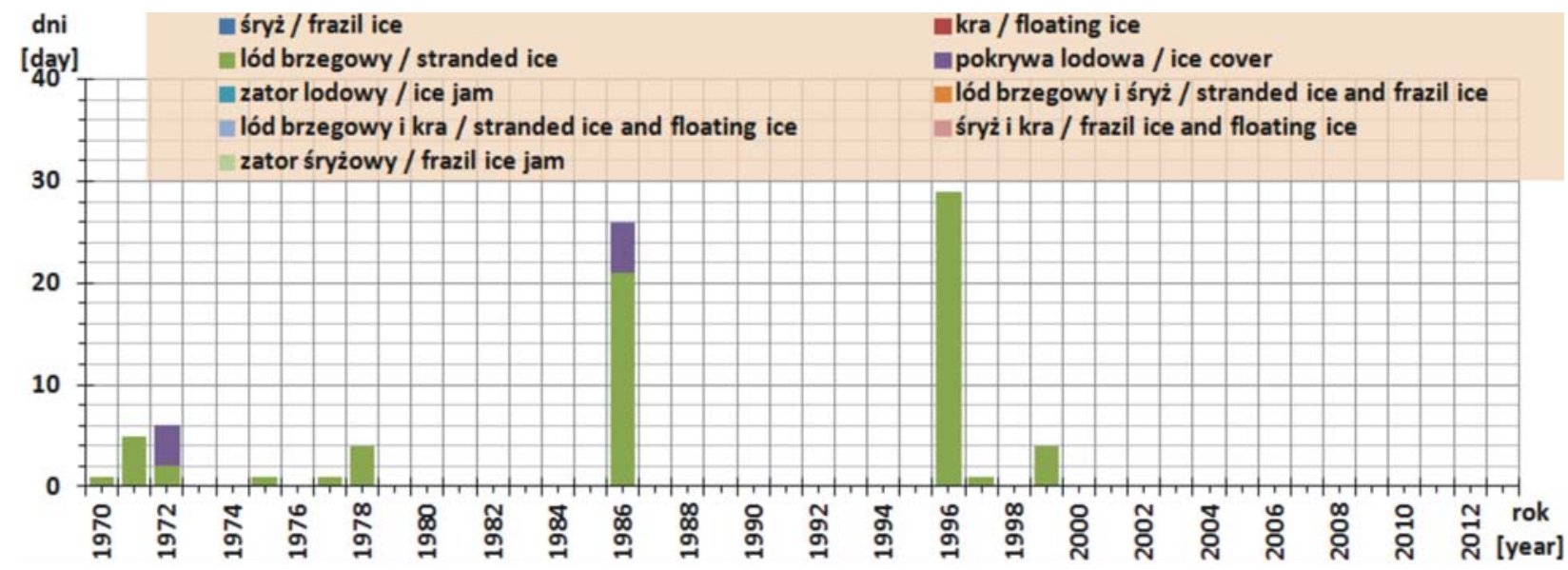

Rys. 17. Liczba dni z określonym typem zjawisk lodowych na rzece Słupi w latach 1970-2013. Stacja wodowskazowa w Soszycy (opracowanie własne)

Fig. 17. The number of days with a certain type of ice phenomena on Słupia River in 1970-2013. The water gauge station in Soszyca (own scientific description) 
Łukaszewicz, J.T. (2017). Przebieg i charakter zjawisk lodowych na wybranych odcinkach rzek Przymorza o wysokim stopniu antropopresji na tle zmian klimatycznych zachodzących w strefie brzegowej Bałtyku. Acta Sci. Pol. Architectura, 16 (1), 93-113. doi: 10.22630/ASPA.2017.16.1.09.

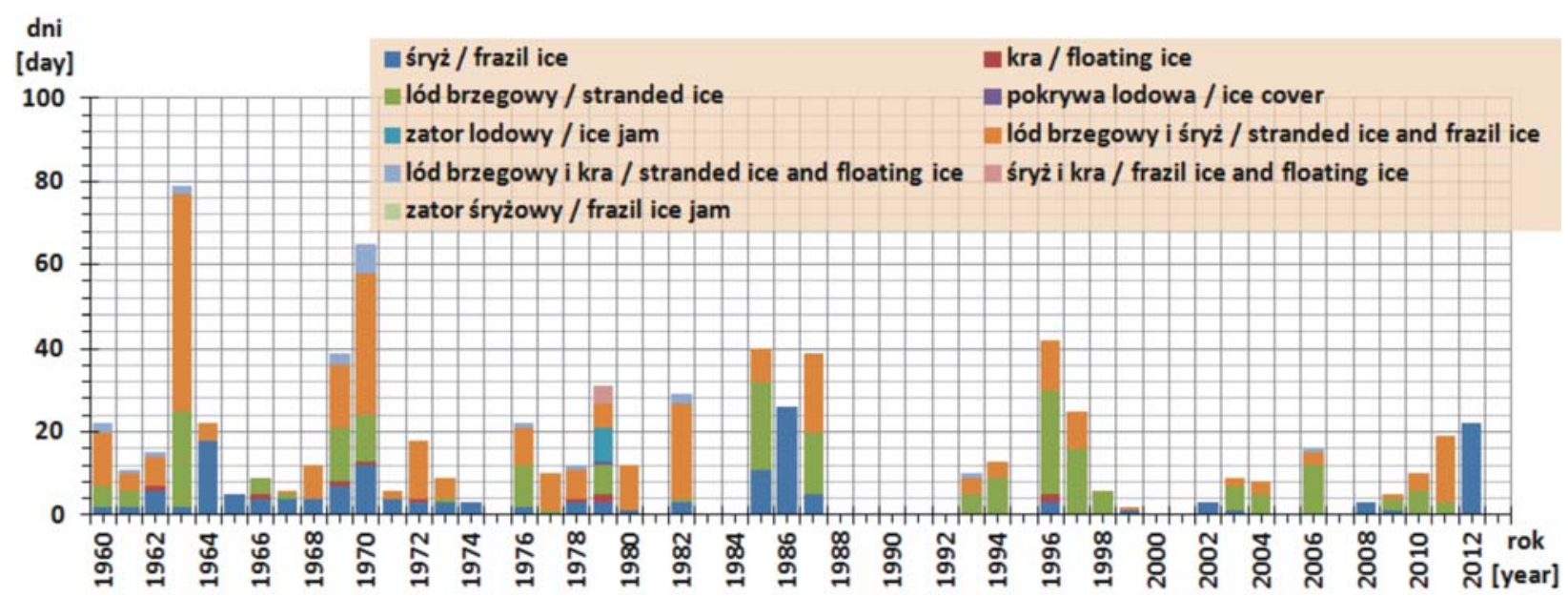

Rys. 18. Liczba dni z określonym typem zjawisk lodowych na rzece Słupi w latach 1960-2013. Stacja wodowskazowa w Słupsku (opracowanie własne)

Fig. 18. The number of days with a certain type of ice phenomena on Słupia River in 1960-2013. The water gauge station in Slupsk (own scientific description)

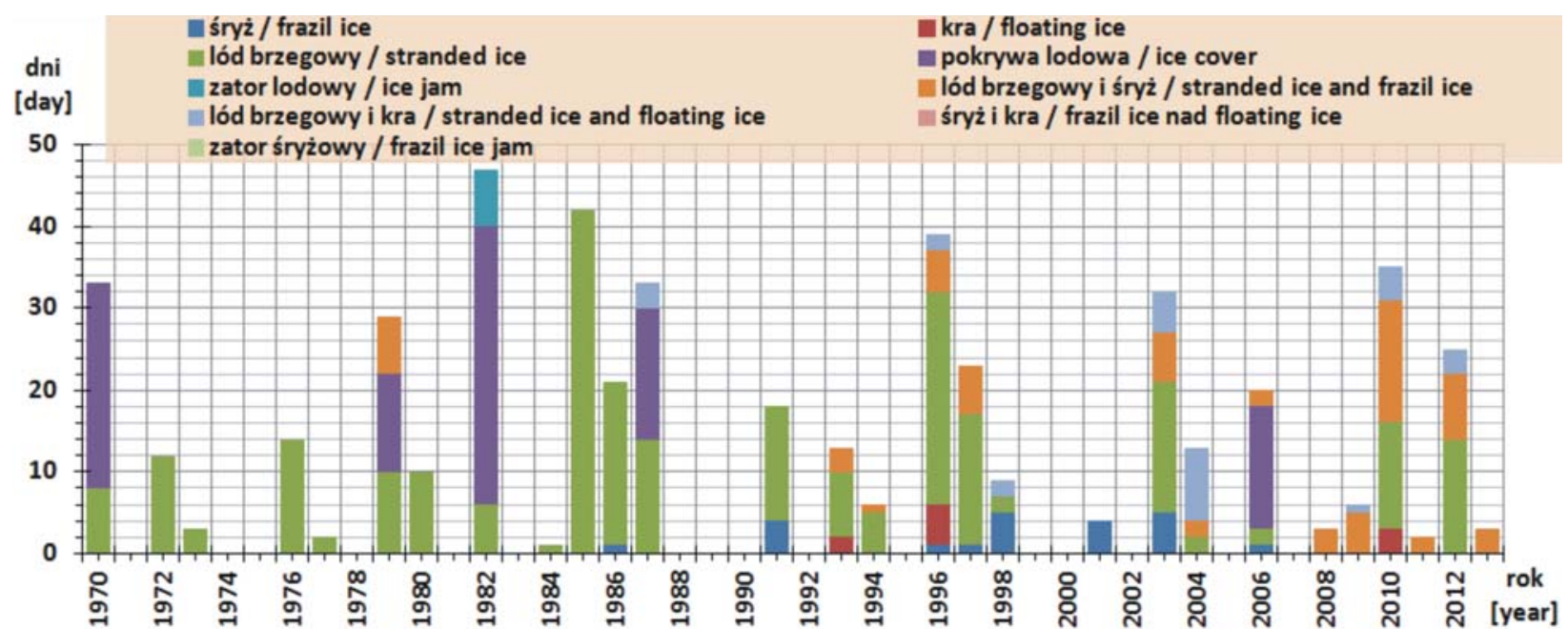

Rys. 19. Liczba dni z określonym typem zjawisk lodowych na rzece Słupi w latach 1970-2013. Stacja wodowskazowa w Charnowie (opracowanie własne)

Fig. 19. The number of days with a certain type of ice phenomena on Stupia River in 1970-2013. The water gauge station in Charnowo (own scientific description)

Druga przyczyna także ma podłoże przyrodnicze. Rzeka w tych miejscach zachowała swój naturalny charakter. Szczególnie widoczne jest to na odcinku w Cecenowie, gdzie stacja pomiarowa graniczy w sposób bezpośredni ze Słowińskim Parkiem Narodowym. Najmniejszą różnorodnością form lodowych i najmniejszą liczbą dni ze zjawiskiem lodowym charakteryzuje się środkowy odcinek rzeki położony przy stacji wodowskazowej w Lęborku. Odcinek ten jest poddany silnej antropopresji. W tym miejscu koryto rzeczne zostało uregulowane. W Lęborku obserwuje się także większy przepływ wód niż w pozostałych stacjach 
Łukaszewicz, J.T. (2017). Przebieg i charakter zjawisk lodowych na wybranych odcinkach rzek Przymorza o wysokim stopniu antropopresji na tle zmian klimatycznych zachodzących w strefie brzegowej Bałtyku. Acta Sci. Pol. Architectura, 16 (1), 93-113. doi: 10.22630/ASPA.2017.16.1.09.

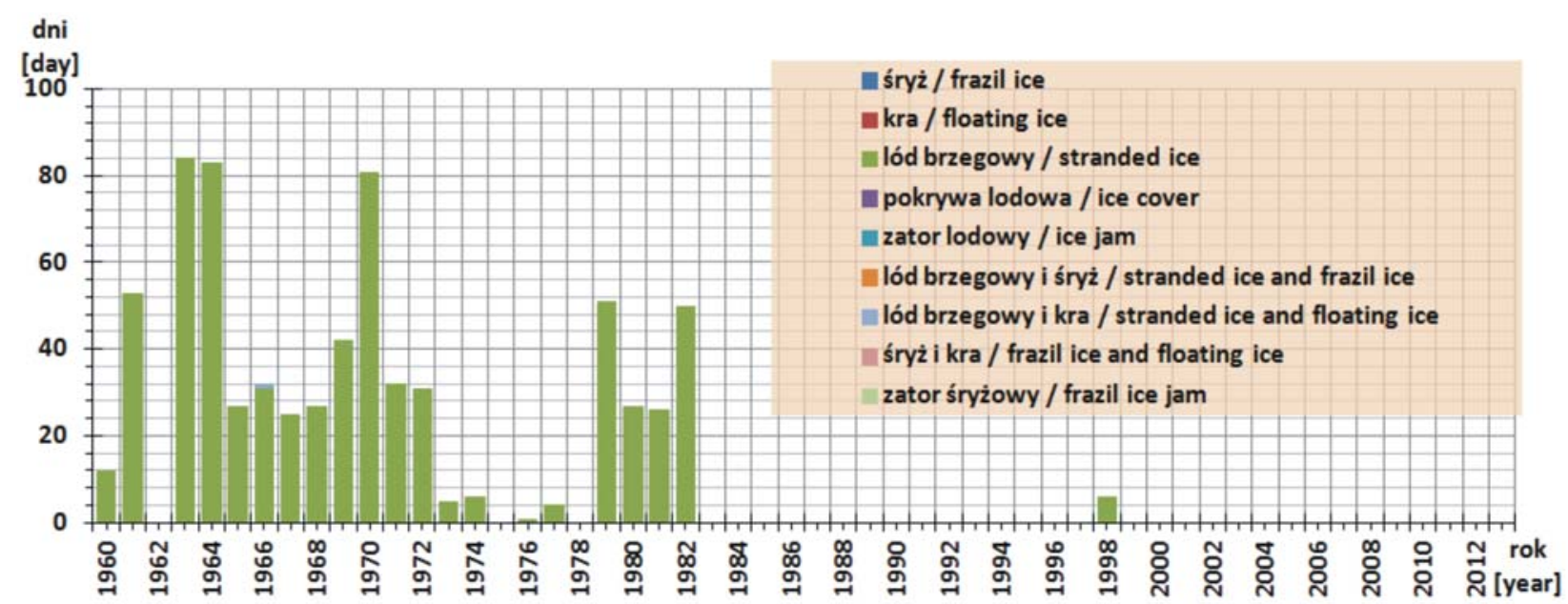

Rys. 20. Liczba dni z określonym typem zjawisk lodowych na rzece Łupawie w latach 1970-2013. Stacja wodowskazowa w Łupawie (opracowanie własne)

Fig. 20. The number of days with a certain type of ice phenomena on Łupawa River in 1970-2013. The water gauge station in Łupawa (own scientific description)

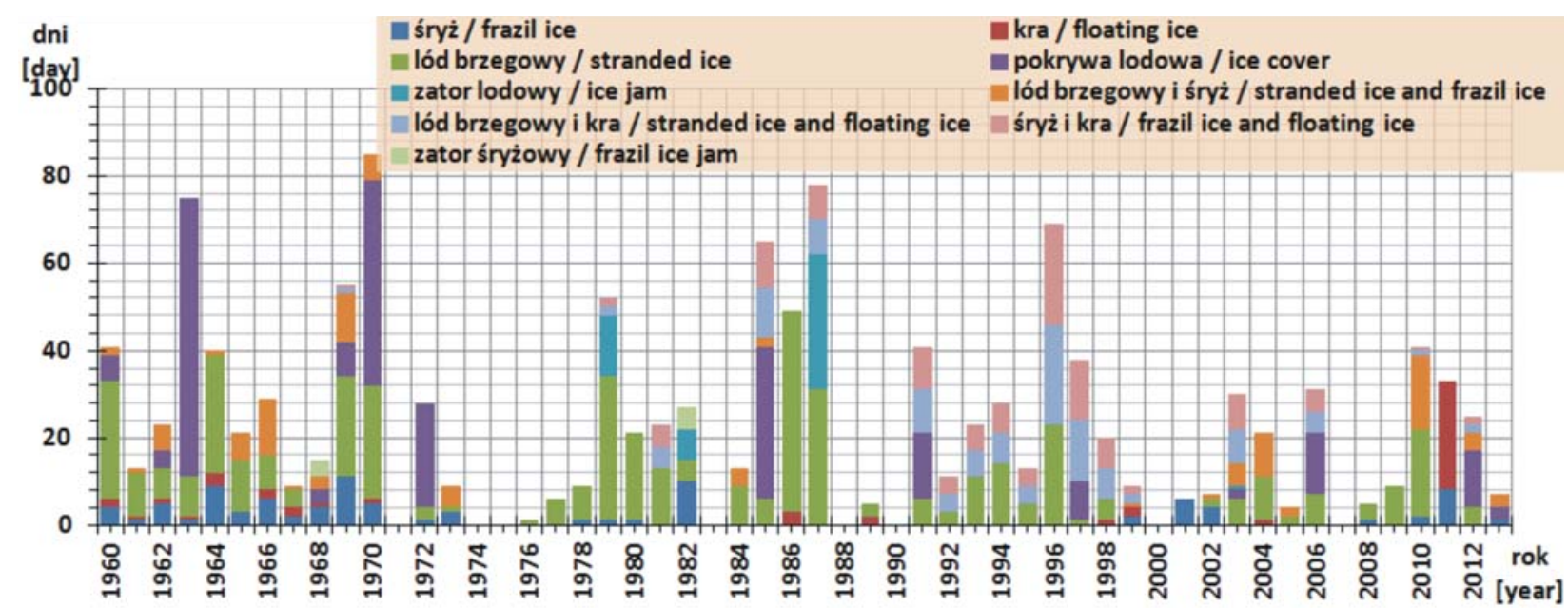

Rys. 21. Liczba dni z określonym typem zjawisk lodowych na rzece Łupawie w latach 1970-2013. Stacja wodowskazowa w Smołdzinie (opracowanie własne)

Fig. 21. The number of days with a certain type of ice phenomena on Łupawa River in 1970-2013. The water gauge station in Smołdzino (own scientific description)

wodowskazowych na rzece Łebie (rys. 7). Na odcinku w Lęborku wybudowano zaporę wodną, która może mieć znaczny wpływ na zmianę czasu trwania zjawisk lodowych.

Wpływ działalności antropogenicznej na występowanie zjawisk lodowych na wybranych rzekach Przymorza, opisanych w niniejszej pracy, nie został jeszcze dostatecznie rozpoznany i wymaga przeprowadzenia kolejnych badań. Na podstawie przeprowadzonych analiz można stwierdzić, że im mniejszy stopień antropopresji w dolinie rzecznej, tym większe jest prawdopodobieństwo wystąpienia zjawiska lodowego na rzece. 
Łukaszewicz, J.T. (2017). Przebieg i charakter zjawisk lodowych na wybranych odcinkach rzek Przymorza o wysokim stopniu antropopresji na tle zmian klimatycznych zachodzących w strefie brzegowej Bałtyku. Acta Sci. Pol. Architectura, 16 (1), 93-113. doi: 10.22630/ASPA.2017.16.1.09.

\section{PODSUMOWANIE I WNIOSKI}

Przeprowadzone badania i obserwacje ciągów pomiarowych wykazały znaczny spadek dni ze zjawiskami lodowymi na rzekach Przymorza, ten ujemny trend można zaobserwować w każdej z badanych zlewni. Sytuacja ta jest spowodowana przede wszystkim zmianami klimatycznymi zachodzącymi w strefie brzegowej Bałtyku, przejawiającymi się wzrostem temperatury powietrza, szczególnie w dwóch ostatnich dekadach obserwacji. Współcześnie zjawiska lodowe pojawiają się coraz później i kończą coraz wcześniej. Dodatni trend przedstawiony we wzroście temperatury powietrza i ujemny w spadku liczby dni, z zaobserwowanym zjawiskiem lodowym na rzekach, jest szczególnie widoczny po 1988 roku, gdzie liczba odnotowanych dni ze zjawiskiem lodowym na rzekach zmniejszyła się prawie o połowę. Trend ten zaobserwowano na każdym z analizowanych posterunków wodowskazowych. Wykazują to także przeprowadzone testy statystyczne Kruskala-Wallisa. Do bezpośrednich przyczyn spadku liczby dni z odnotowanym zjawiskiem lodowym można zaliczyć zarówno wzrost średniej rocznej temperatury powietrza $\mathrm{w}$ okresie zimowym, jak i wzrost temperatury w chłodnym półroczu roku hydrologicznego, co ma bezpośredni wpływ na wzrost temperatury wody w profilu rzek w tym okresie. Badania wykazały także, że jedną z przyczyn wzrostu temperatury powietrza w strefie brzegowej Bałtyku jest wzrost procentowy pozytywnej fazy oscylacji północnoatlantyckiej, a także wzrost wartości indeksu Jonesa, szczególnie widoczny w dwóch ostatnich dekadach obserwacji, który ma bezpośredni wpływ na dominację ciepłych i wilgotnych zim na tym obszarze.

Uzyskane w pracy wyniki znajdują swoje potwierdzenie we wcześniej przeprowadzonych badaniach. Analiza danych wykonana przez Filipiaka (2004) wykazała, że w drugiej połowie XX wieku na obszarze Przymorza wystąpił dodatni trend temperatury powietrza w sezonie zimowym. Podobne wyniki otrzymał Kożuchowski (2000, 2011), analizując przebieg temperatury powietrza w Polsce w latach 1959-1968 i 1989-1998. Wykazal on, że nastąpił rozwój oceanizmu klimatycznego, który wpłynął w bezpośredni sposób na złagodzenie zimy. Otrzymane wyniki wykazują także dużą zgodność z badaniami przeprowadzonymi przez Choińskiego, Ławniczaka i Ptaka (2013), którzy badając tendencje zmian zjawisk lodowych na jeziorach Polski w latach 1951-2010 , wykazali skrócenie czasu trwania zjawisk lodowych na tych zbiornikach. Podobne wyniki otrzymali także Marszelewski i Skowron (2006).

Z uzyskanych w pracy wyników można także stwierdzić, że zmiany klimatyczne mają szczególny wpływ na czas trwania zjawisk lodowych na rzece, lecz nie mają tak istotnego wpływu na typ zlodzenia. Na odcinkach rzek znajdujących się w strefach niezurbanizowanych lub słabo zurbanizowanych i odcinkach poddanych mniejszej antropopresji można zaobserwować wszystkie typy zlodzenia, niezależnie od okresu obserwacji. Natomiast na odcinkach charakteryzujących się wysokim stopniem antropopresji, szczególnie tam, gdzie koryto jest zabudowane, rzadko obserwuje się pokrywę lodową lub nie obserwuje się jej wcale.

Na podstawie przeprowadzonych obserwacji można stwierdzić, że uzyskane w pracy wyniki potwierdzają postawioną hipotezę. Działalność antropogeniczna prowadzona w obrębie doliny rzecznej w znacznym stopniu wpływa na zmianę typu zlodzenia i formę lodu obserwowaną na rzekach oraz na czas trwania zjawisk lodowych.

Istotną rolę w zmianie czasu trwania oraz przebiegu zjawisk lodowych ma także budowa zbiorników zaporowych i elektrowni wodnych, które w znacznym stopniu przyczyniają się do skrócenia czasu trwania zjawisk lodowych na odcinkach rzek położonych poniżej zapory wodnej zbiornika. W pracy szczególnie widoczne jest to poniżej zbiornika zaporowego Krzynia, znajdującego się powyżej stacji wodowskazowej w Słupsku, i zbiornika Żukówko, zlokalizowanego powyżej stacji wodowskazowej w Soszycy. Na tych stacjach liczba dni z pokrywą lodową jest znikoma w porównaniu z posterunkiem w Charnowie. Podobną zależność można zaobserwować w punkcie pomiarowym w Lęborku, gdzie koryto jest zabudowane, a odcinek, na którym prowadzono obserwacje, znajduje się poniżej zapory wodnej. Potwierdzenie tej hipotezy można znaleźć także w badaniach przeprowadzonych przez Cyberską (1972), Grzesia i Pawłowskiego (2006), Sergeevicha 
Łukaszewicz, J.T. (2017). Przebieg i charakter zjawisk lodowych na wybranych odcinkach rzek Przymorza o wysokim stopniu antropopresji na tle zmian klimatycznych zachodzących w strefie brzegowej Bałtyku. Acta Sci. Pol. Architectura, 16 (1), 93-113. doi: 10.22630/ASPA.2017.16.1.09.

(2009) oraz Wiejaczkę (2011). Badania przeprowadzone przez tych autorów potwierdzają wpływ antropopresji, objawiający się w sposób szczególny w przekształceniach biegu koryta, a także w budowie zbiorników zaporowych na rzece, wpływ nie tylko na zmianę czasu trwania zjawisk lodowych, ale także na zmianę typu genetycznego lodu obserwowanego na rzece. Na przykład na rzece Słupi skrócenie koryta i jego regulacja przyczyniły się do zwiększenia przepływu, a to wpłynęło bezpośrednio na mniejszą liczbę dni z zaobserwowanym zjawiskiem lodowym na rzece.

Wyniki otrzymane w pracy mogą stanowić podstawę do dalszych badań dotyczących przebiegu i zmian zjawisk lodowych na rzekach Przymorza oraz dać odniesienie do wcześniej przeprowadzonych badań zlodzeń na rzekach polskich. Mogą także stanowić podstawę klasyfikacji zimowego reżimu termicznego tych rzek.

\section{PIŚMIENNICTWO}

Allan, J. D. (1998). Ekologia wód płynących. Warszawa: Wydawnictwo Naukowe PWN.

Babiński, Z. (1985). Hydromorfologiczne konsekwencje regulacji Wisły. Przeglad Geograficzny, 57(4), 471-486.

Banach, M. (1994). Morfodynamika strefy brzegowej zbiornika Włocławek. Wrocław: Wydawnictwo PAN.

Banach, M. (2007). O zachwianiu procesu ewolucji brzegów zbiornika Włocławek. Słupskie Prace Geograficzne, 3, 95-106.

Baranowski, D. (2008a). Cechy dynamiczne klimatu Polski i ich wpływ na pole temperatury. Słupsk: Wydawnictwo Akademii Pomorskiej w Słupsku.

Baranowski, D. (2008b). Warunki klimatyczne Ustki. Stupskie Prace Geograficzne, 5, 101-111.

Braniecki, A. i Biegała, L. (1985). Charakterystyka przebiegu zlodzenia Wisły przed i po spiętrzeniu stopniem Włocławek. W W. Majewski (red.), Powódź zatorowa na Wiśle w rejonie Zbiornika Włocławek w zimnie 1982 r., Komitet Gospodarki Wodnej PAN, Seria Monografie (strony 50-67). Warszawa: Wydawnictwa Geologiczne.

Choiński, A., Ławniczak, A. i Ptak, M. (2013). Charakterystyka zlodzenia jezior Wielkopolskiego Parku Narodowego i jego otuliny. Badania Fizjograficzne, A, 63, 39-50.

Cyberska, B. (1972). Zmiany w temperaturze i zlodzeniu rzek poniżej zbiorników retencyjnych. Gospodarka Wodna, 7 , $244-250$

Dobrowolski, A. B. (1923). Historia naturalna lodu. Warszawa: Wydawnictwo Kasy Pomocy im. J. Mianowskiego.

Filipiak, J. (2004). Zmienność temperatury powietrza na Wybrzeżu i Pojezierzu Pomorskim w drugiej połowie XX w. Warszawa: Wydawnictwo IMGW.

Gerstmannowa, E. i Zalewski, W. (2001). Plan ochrony Parku Krajobrazowego „,Dolina Stupi” (PKDS) - synteza ustaleń. W E. Gerstmannowa (red.), Materiały do monografii przyrodniczej regionu gdańskiego. Tom 5. Park Krajobrazowy Dolina Stupi. Gdańsk: Wydawnictwo Gdańskie.

Gerstmannowa, E., Florek, E. i Konarski, P. (2001). Walory i zagospodarowanie turystyczne parku „Dolina Słupi”. W E. Gerstmannowa (red.), Materialy do monografii przyrodniczej regionu gdańskiego. Tom. 5. Park Krajobrazowy Dolina Stupi. Gdańsk: Wydawnictwo Gdańskie.

Girjatowicz, J. P., Świątek M. i Olechwir, T. (2002). Związki oscylacji północnoatlantyckiej z warunkami lodowymi polskiego wybrzeża. W A. Marsz, A. Styszyńska A. (red.), Oscylacja pótnocnego Atlantyku i jej rola w kształtowaniu zmienności warunków klimatycznych i hydrologicznych Polski (strony 191-203). Gdynia: Wydawnictwo Uczelniane Wyższej Szkoły Morskiej.

Gołek, J. (1957). Zjawiska lodowe na rzekach polskich. Prace Państwowego Instytutu Hydrologiczno-Meteorologicznego, 48. Warszawa: Wydawnictwa Komunikacyjne.

Gołek, J. (1964). Zlodzenie rzek polskich. Prace PIHM, 63. Warszawa: Wydawnictwa Komunikacyjne.

Gorączko, M. i Pawłowski, B. (2014). Przebieg zjawisk lodowych na Warcie w rejonie Uniejowa. Biuletyn Uniejowski, 3, 21-33.

Grześ, M. (1991). Zatory i powodzie zatorowe na dolnej Wiśle - mechanizmy i warunki. Warszawa: Wydawnictwo Instytut Geografii i Przestrzennego Zagospodarowania PAN.

Grześ, M. (1999). Rola zjawisk lodowych w kształtowaniu koryta dolnej Wisły. Acta Universitatis Nicolai Copernici, Nauki Matematyczno-Przyrodnicze, Geografia, 103, 113-128. 
Łukaszewicz, J.T. (2017). Przebieg i charakter zjawisk lodowych na wybranych odcinkach rzek Przymorza o wysokim stopniu antropopresji na tle zmian klimatycznych zachodzących w strefie brzegowej Bałtyku. Acta Sci. Pol. Architectura, 16 (1), 93-113. doi: 10.22630/ASPA.2017.16.1.09.

Grześ, M. i Pawłowski, B. (2006). Metody identyfikacji zatorowych odcinków rzek. W P. Gierszewski i M. T. Karasiewicz (red.), Idee i praktyczny uniwersalizm geografii - Geografia Fizyczna (strony 94-98). Warszawa: Instytut Geografii i Przestrzennego Zagospodarowania PAN.

Janc, E. i Krukowicz, A. (1987). Wyznaczanie stref zagrożenia powodziowego i zasady lokalizacji obiektów gospodarki narodowej w tych strefach. Informator Projektanta CBSiPBW „Hydroprojekt”, 3, 11-17.

Kiciński, T. i Ciepielowski, A. (1975). Ochrona przed powodzia. Warszawa: Stowarzyszenie Inżynierów i Techników Wodnych i Melioracyjnych.

Kondracki, J. (2009). Geografia regionalna Polski. Warszawa: Wydawnictwo Naukowe PWN.

Kornaś, M. (2014). Ice phenomena in the Warta River in Poznań in 1961-2010. Questiones Geographice, 33(1), 51-59.

Kożuchowski, K. (2000). Pory roku w Polsce. Sezonowe zmiany w środowisku a wieloletnie tendencje klimatyczne. Łódź: Wydawnictwo Zakładu Dynamiki Środowiska i Bioklimatologii Uniwersytetu Łódzkiego.

Kożuchowski, K. (2011). Klimat Polski. Nowe spojrzenie. Warszawa: Wydawnictwo Naukowe PWN.

Lambor, J. (1948). Geneza lodu prądowego i jego pojawianie się na rzekach środkowoeuropejskich zlewiska Morza Bałtyckiego. Wiadomości Stużby Hydrologiczno-Meteorologicznej, I, 3, 213-244.

Lambor, J. (1959). Zjawiska lodowe na śródlądowych drogach wodnych w Polsce. Prace i Studia Komitetu Gospodarki Wodnej, Prace Hydrologiczne, II, 1, 121-138.

Majewski, W. (1985). Opory przepływu wywołane pokrywą lodową. W W. Majewski (red.), Powódź zatorowa na Wiśle w rejonie zbiornika ,Włocławek” w zimie 1982 r. Komitet Gospodarki Wodnej PAN, Seria Monografie (strony 218 -225). Warszawa: Wydawnictwa Geologiczne.

Majewski, W. (1987). Wpływ pokrywy lodowej na charakterystyke hydrauliczna zbiorników przeptywowych na rzekach nizinnych na przykładzie zbiornika Włocławek. Gdańsk: Prace Instytutu Budownictwa Wodnego PAN.

Majewski, W. (2009). Przeplywy w korytach otwartych z uwzględnieniem zjawisk lodowych. Warszawa: IMGW.

Marszelewski, W. i Skowron, R. (2006). Ice cover as and indicator of winter air temperature changes. Case study of the Polish Lowland lakes. Hydrological Sciences Journal, 51(2), 336-349. doi: 10.1623/hysj.51.2.336.

Niedźwiedź, T. (2002). Relacje między NAO a wskaźnikiem cyrkulacji nad Polską. W A. Marsz i A. Styszyńska (red.), Oscylacja Pótnocnego Atlantyku i jej rola w ksztaltowaniu zmienności warunków klimatycznych i hydrologicznych Polski (strony 87-97). Gdynia: Wydawnictwo Uczelniane Wyższej Szkoły Morskiej.

Okołowicz, W. i Martyn, D. (1984). Regiony klimatyczne. Atlas Geograficzny Polski. Warszawa: Państwowe Przedsiębiorstwo Wydawnictw Kartograficznych.

Pasławski, Z. (1970). Wpływ zjawisk lodowych na przepływ rzeczny. Prace PIHM, 99, 3-40

Pawłowski, B. (2008a). Wieloletnia zmienność przebiegu zjawisk lodowych na Wiśle w Toruniu. Gospodarka Wodna, 2, 49-53.

Pawłowski, B. (2008b). Zmienność geometrii koryta dolnej Wisły w okresie zlodzenia rzeki. Gospodarka Wodna, 7, 276-280 .

Pawłowski, B. i Sobota, I. (2012). Zlodzenie dolnej Wisły powyżej zapory we Włocławku zima 2011 r. Gospodarka Wodna, 2, 74-77.

Romer, E. (1949). Regiony klimatyczne Polski. Wrocław: Prace Wrocławskiego Towarzystwa Naukowego.

Sergeevich, K. M. (2009). The Influence of the river reservoirs of Belarus on hydrological river regime and channel operation processes in the downstream. УДК 556.53:627.8-33(476).

Wiejaczka, Ł. (2011). Wpływ zbiornika wodnego „,Klimkówka” na abiotyczne elementy środowiska w dolinie rzeki Ropy. Prace Geograficzne 229. Warszawa: IGiPZ PAN.

Wokroj, J. (1954). Powodzie zatorowe i walka z nimi. Gospodarka Wodna, 4, 141-142.

Woś, A. (1996). Zarys klimatu Polski. Poznań: Wydawnictwo Naukowe Uniwersytetu im. Adama Mickiewicza.

Woś, A. (1999). Klimat Polski. Warszawa: Wydawnictwo Naukowe PWN. 
Łukaszewicz, J.T. (2017). Przebieg i charakter zjawisk lodowych na wybranych odcinkach rzek Przymorza o wysokim stopniu antropopresji na tle zmian klimatycznych zachodzących w strefie brzegowej Bałtyku. Acta Sci. Pol. Architectura, 16 (1), 93-113. doi: 10.22630/ASPA.2017.16.1.09.

\title{
THE COURSE AND THE CHARACTER OF THE ICE PHENOMENA IN SELECTED SECTIONS OF PRZYMORZE RIVERS WITH A HIGH INFLUENCE OF ANTHROPOPRESSURE IN RELATION TO THE CLIMATE CHANGES THAT OCCUR IN THE COASTAL ZONE OF THE BALTIC SEA
}

\begin{abstract}
The article presents the characteristics of the incidence and course and variability of the ice phenomena on selected sections of rivers in Przymorze which are influenced by a high level of human pressure. The study also includes the variability of forms of the ice phenomena occurring on the rivers taking into account the structure and the type of ice, which appeared in various phases of ice cover on rivers. When analyzing the variability of ice phenomena into account a number of factors; among other things, the location section of the river, which conducted the observations, the water flow in the profile of the river, the variability of water temperature in the winter and its impact on the number of days with the phenomena of ice on rivers and variability of air temperature during the winter and cool half of hydrological year, that the main factors conditioning the formation of ice phenomena on rivers. The work also included the course of the atmospheric circulation, which determines the course of the air temperature. To describe these changes, the indicator used the North Atlantic Oscillation.
\end{abstract}

Key words: ice phenomena, ice cover, temperature, flow, climate change 